CHAPTER SIX

\title{
PLAYING (THE) GOD \\ DID (THE) GREEKS BELIEVE IN THE DIVINITY OF THEIR RULERS?
}

"It is all playacting of course," he said, "but in her case the difference is that she believes in the role she plays. For myself, I find I do not care."

J.M. Coetzee, Waiting for the Barbarians, 46

\section{Men into Gods}

\section{A swollen-headed doctor: the case of Menekrates}

One day in the year 340 BC the Syracusan physician Menekrates felt hungry. This doctor, whose life spanned the greater part of the fourth century $\mathrm{BC},{ }^{1}$ had reaped laurels with his superhuman miracle cures. He even boasted the power to heal epilepsy, the sacred disease, which pace [Hippocrates]' treatise on the subject was generally believed to be sent by the gods and hence denied normal treatment. Healing patients who are given up by doctors ${ }^{2}$ was, in Greek eyes, a miracle reserved for gods, for Asklepios in particular as we have seen. And Menekrates agreed. Defying Pindar's maxim "do not aspire to

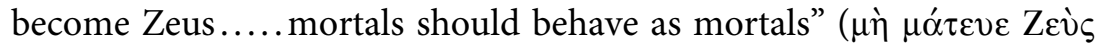

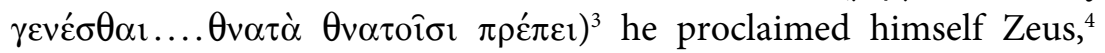

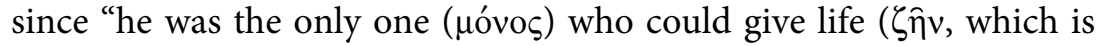
an accusative form of the name Zeus as well) to people through his medical art." ${ }^{\prime 5}$ Let us keep this in mind: an etymological pun serving as

\footnotetext{
${ }^{1} \mathrm{He}$ is mentioned in the context of Agesilaos ( $†$ 361) and Alexarchos ( $\dagger$ after 300).

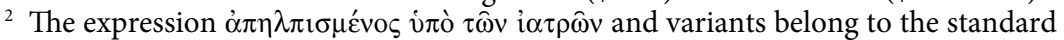
formulas of stories about healing miracles: Weinreich 1909, $195 \mathrm{ff}$.

${ }^{3}$ Pind. Isthm. 5.14. Cf. Ol. 5.24.

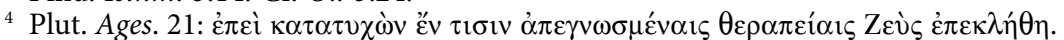

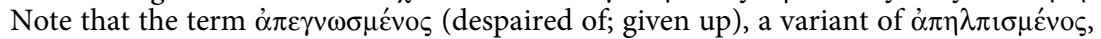
belongs to the formulaic expressions referred to above n. 2 .

${ }^{5}$ So, literally, Athen. 289A. The word-play is no doubt deliberate since the same expression returns at the end of Menekrates' letter to king Philip (Athen. 289D).
} 
an instrument in the process of divinisation. ${ }^{6}$ Accordingly, Menekrates dressed up as the King of the gods and travelled around accompanied by a retinue of followers personifying other gods. ${ }^{7}$

Unlike Asklepios, Menekrates did not charge his patients an honorarium but had them promise that after their recovery they would serve as slaves ( $\left.\delta \circ \hat{\imath} \lambda_{0}\right)$ in his retinue. Menekrates himself wore a purple gown, a golden wreath and a sceptre, and krepides on his feet, all of which were characteristic of (Hellenistic) rulers and gods, especially of Zeus Basileus. Albeit his douloi, his followers were also dignitaries (just as at the Persian court the aristocrats were the slaves of the king) and, indeed, gods: Herakles was impersonated by Nikostratos of Argos, the same man who as a general had fought a battle dressed in a Heraklean outfit around $350 \mathrm{BC} .{ }^{8}$ Hermes was impersonated by Nikagoras, the last tyrant of Zela, Apollo by a certain Astukreon, and an anonymous played Asklepios.

Clement of Alexandria contributes one more divine doulos to the list-"a foot-note on the pages of history, but a not uninteresting one." It is Alexarchos, the learned brother of Kassandros, the later king of Macedonia, who, if at all, can only have been a junior member of the club of celestials, where he played the role of Helios (the Sungod). ${ }^{10}$ In accordance with that name he had founded a city bearing the appropriate name of Ouranopolis, 'City of heaven', on the Athos peninsula. We have solid evidence proving the accuracy of this

\footnotetext{
${ }^{6}$ Nor is this all. According to Weinreich the use of the term monos may have originated as an acclamation by his followers "there is only one Menekrates-Zeus," in accordance with the endless cheers heis, or monos for both gods and important people. Cf. Norden 1923, 243-250; Versnel 1990, Ch. III, and our discussions in Chs. II and V. Especially noteworthy in this connection is the expression handed down by

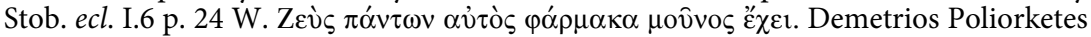

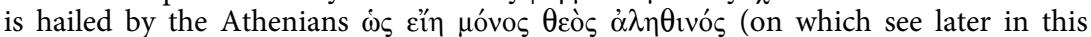

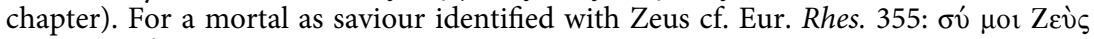

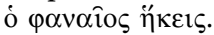

7 Athen. 7.289 is our main source. Cf. further: Clem. Al. Protr. 4.54; Ael. VH 12.51; Suda s.v. The evidence is quoted in full in what is still the fundamental study on Menekrates: O. Weinreich, Menekrates Zeus und Salmoneus, Tüb. Beiträge Altert. Wissensch. $18(1933)=$ Weinreich 1968, 299-429, espec. $396 \mathrm{ff}$.

${ }^{8}$ Diod. 16.44.3. "Man wird darin kaum mehr als blosse Maskerade eines bramarbasierenden alten Soldaten sehen dürfen und die Parallelen nicht auf dem Felde des Herrscherkultes, sondern auf dem der sattsam bekannten griechischen Eitelkeit suchen müssen" (Taeger I, 1957, 165).

${ }^{9}$ Ferguson 1975, 108, who gives a brief survey of the evidence at pp. $108 \mathrm{ff}$.

${ }^{10} \mathrm{He}$ was certainly younger than his brother, who was born not long before 350 BC. On Alexarchos see: Tarn 1948, II 431 ff., though his theory is misguided.
} 
account: a number of curious coins display astral symbols: sun, moon,

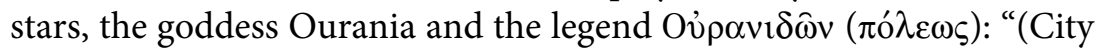
of) the children of Heaven." In a letter Alexarchos seems to address his friends as $\dot{\eta} \lambda$ เокр $\alpha \tau \varepsilon i \varsigma$ ("ruled by Helios", i.e. by himself). "Seems," for the letter is written in a very bizarre home-cooked Greek, the dialect which was introduced by the king at the foundation of the city, a lingo so odd indeed that Athenaeus 3.98E "doubts whether even the Delphic oracle could make sense of this letter." Although the linguistic base is clearly recognizable as Greek, considerable parts of the letter remain enigmatic and we can only guess at their meaning. But the agenda behind the creation of a partly incomprehensible language is not enigmatic at all: it was surely intended to represent the language of celestials, since as we have seen in $\mathrm{Ch}$. V, for those who wish to press distinctions between gods and men, gods indeed had their own language different from that of mortals.

This experiment confronts us with a first striking instance of that strange 'double awareness' of human and divine characteristics in a simultaneous interplay for which the Greek language has a perfect term in $\dot{\pi} \pi \mu \varphi$ $\alpha \varepsilon \rho^{\prime} \zeta \varepsilon v v$, 'play a double game' or 'run with the hare and hunt with the hounds. ${ }^{11}$ 'Behaving ambiguously' by means of rôle-

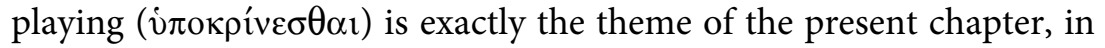
which I will pay attention to the elements of double awareness ${ }^{12}$ and the ambiguity of the ludic in the deification of mortals. In hindsight, this will also shed light on themes that we have treated in previous chapters.

Already in antiquity, the singular behaviour of Menekrates and his consorts has been explained as a symptom of mania or melancholia, and modern scholars, Weinreich in particular, ${ }^{13}$ have pursued this track and tried to explain it predominantly in terms of psychopathological deviations. There may be a point in this, but I shall argue that

${ }^{11}$ Most illustrative is a passage in Epictetus 2.9.19-20, where he urges the Epicureans not to pretend but to genuinely live like Epicureans, thus illuminating his argument:

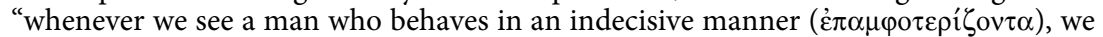
are in the habit of saying: "He is not a Jew, he is only acting the part (i

${ }_{12}$ The term was introduced by Pruyser 1968, 190.

${ }_{13}$ But he is not alone. Taeger I 1957, 157, for instance writes: "Wehen um die Wundermänner der Vergangenheit noch die Schauer echten Glaubens, so vereinigen sich hier Wahn und Unglaube zu einer makabren Szene." Taeger takes an extremely sceptical stance towards the whole tradition concerning this and other divine men, in which not many would follow him today. I have given a critique of this ill-founded scepticism in Versnel 1974, $139 \mathrm{ff}$. 
it is unwise to single out and isolate this particular aspect. ${ }^{14}$ The period under discussion simply boasts too many similar 'megalomaniac' individuals ${ }^{15}$ to hospitalize them all indiscriminately.

Take, for instance, also in the fourth century BC, Klearchos, tyrant of Heraklea 363-352, student of Plato and founder of the first known public library. ${ }^{16}$ So, he cannot possibly have been that mad. Yet he had no scruples in proclaiming himself son of Zeus, and in dressing up accordingly: purple gown, golden wreath, sceptre and lightning. The theatrical atmosphere of role-playing ${ }^{17}$-very similar to that of Menekrates-is enhanced by his kothurnoi (theatrical boots), the eagle carried before him, and most of all by his red painted face, as it befits a god. He was honoured with an altar and gave his son the name Keraunios ('Little Lightning').

It may be of some significance that Euhemeros of Messene (who lived from mid 4th century well into the third), the one who argued that gods were former kings and generals deified after their death, ${ }^{18}$ also belonged to the circle of king Kassandros. Euhemeros' design of a utopian community in his novel 'Sacred Scripture'19 may have been the source of inspiration for Alexarchos, just as-more relevant to our issue - the idea of deification of mortal beings may have had its effects on contemporary ruler cult. In the words of S. Hornblower:

Euhemerism could be interpreted according to taste as supporting the traditional belief of Greek epic and lyric poetry which drew no clear line

${ }^{14}$ Cf. V. Nutton, Neue Pauly 7 (1999) 1229: "Der Respekt, den medizinische Schriftsteller späterer Zeiten seinen Ansichten zollten, spricht allerdings dafür, dass er nicht immer der verrückte Hanswurst war, als der er oft karikiert wurde."

${ }^{15}$ On Parrhasios, Kleitos and others see: Cerfaux-Tondriau 1957, indices s.v., especially the section 'Assimilations à des divinités à la période classique', $469 \mathrm{ff}$.

${ }^{16}$ On Klearchos: H. Apel, Die Tyrannis von Heraklea (Diss. Halle 1919); CerfauxTondriau 1957, 470; Taeger I 1957, 164 f.; Weinreich 1968, 321; K. Trampedach, Platon, die Akademie und die zeitgenössische Politik (Hermes Einzelschr. 66, 1994) 79-87, with the connections with Plato at $84 \mathrm{ff}$.

${ }_{17}$ This has been especially emphasized by A. Alföldi, Gewaltherrscher und Theaterkönige, in: Late Classical and Medieval Studies in Honor of Albert Matthias Friend jr. (Princeton 1955) $15 \mathrm{ff}$. We shall return to this aspect later.

18 Plut. Mor. 360A. See: K. Sacks, Diodorus Siculus and the First Century (Princeton 1990) 70-82.

19 Ferguson 1975, 102-110; B. Kytzler, Zum utopischen Roman der klassischen Antike, in: H. Hofmann (ed.), Groningen Colloquia on the Novel 1 (1988) 7-16. Full discussion in M. Winiarczyk, Euhemeros von Messene. Leben, Werk und Nachwirkung (Beitr. z. Altertumsk. 157, Munich-Leipzig 2002). 
between gods and great men; as advancing a justification for contemporary ruler-cults; or as a work of rationalizing atheism. ${ }^{20}$

In the meantime, the hunger of Menekrates Zeus has become agonizing. The main reason is that, at this particular point of our story, together with his divine companions, he is a guest at a banquet of Philippos II, king of Macedonia, and notices with delight how his table companions are being served with a choice of delicacies. ${ }^{21}$ However, when it is his turn, being a god he is honoured with a special privilege, a theoxenion, consisting of aparchai-first fruits of the fields dished up on a trapeza, a cult table-as well as with an altar on which the stewards make libations, and an incense burner on which they burn incense. Although-as Aelian tells us-Menekrates Zeus is at first mightily pleased with this recognition of his divine status, finally, when libation and incense turn out to be his entire menu, his hunger, never satisfied, "exposes him as a human being, and a stupid one at that." So he rises and shamefully slinks off.

Of course, festive symposia cry out for comic interludes. ${ }^{22}$ Moreover king Philippos was fond of excessive blow-outs, ${ }^{23}$ and he was a notorious lover of jokes. ${ }^{24}$ Consequently, the authenticity of the puns

20 S. Hornblower, art. Euhemerus in OCD. Cf. M. Fusillo, Neue Pauly 4, 1998, 236: "Ausser Zweifel steht ein direkter Bezug zur hell. Praxis der Vergöttlichung von Herrschern." Reflections on the relationship between the Euhemeros of 'Euhemerism'

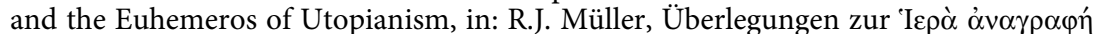
des Euhemeros von Messene, Hermes 121 (1993) 276-300. Cf. Winiarczyk o.c. (preceding note), Chapters 4 and 7.

${ }^{21}$ Athen. 289EF; Ael. VH 12.51. Weinreich 1968, Beilage 1 C, p. 401.

22 During a dinner at the court of Ptolemaios III, the Jewish guest Hyrkanos was the target of a practical joke very much comparable with the one of Menekrates. He got his table filled with a heap of gnawed bones (Jos. AJ $12.173 \mathrm{ff}$.). On practical jokers (at royal banquets): J. Martin, Symposium. Die Geschichte einer literarischen Form (Paderborn 1931), 51-64, on 'Spaßmacher' ( $\gamma \varepsilon \lambda \omega \tau$ oлoıo') and their activities at symposia; K. Vössing, Mensa Regia: Das Bankett beim hellenistischen König und beim römischen Kaiser (Munich-Leipzig 2004) $158 \mathrm{f}$. with Hyrkanos at $133 \mathrm{f}$. For the Greek novel see: C. Jouanna, Un topos oublié: les scènes de banquets, REG 109 (1996) 157-184, espec. 178 ff. For symposiac joking and mocking at Rome see: M. Peachin, Friendship and Abuse at the Dinner Table, in: idem (ed.), Aspects of Friendship in the Graeco-Roman World. Proceedings of a Conference at Heidelberg 2000 (Portsmouth 2001) 135-144. For Philippos' festive dinners see: F. Pownall, The Symposia of Philip II and Alexander III of Macedon: The View from Greece, in: Carney \& Ogden 2010, 55-65.

${ }^{23}$ Athen. 6.76.260BC. Cf. K. Vössing, Mensa Regia. Das Bankett beim hellenistischen König und beim römischen Kaiser (Munich-Leipzig 2004) 67-70, with Menekrates at p. 89.

${ }^{24}$ Compare his laconic answer to a letter of Menekrates which the doctor had signed off with "I, being Zeus, give life," whereupon the king writes back: "Philippos 
and practical jokes attributed to him cannot be warranted. Nor can the whole scene just described. However, authenticity is immaterial to the present issue, which is not about persons and actual historicity but about the cultural mentality that may provoke either such an action or such an anecdote.

\section{A charismatic prince: the case of Demetrios Poliorketes}

Some fifty years later, most probably in 290 BC, King Demetrios Poliorketes made his last visit to Athens. ${ }^{25}$ On the occasion of his entry, ${ }^{26}$ the Athenians welcomed him with incense ${ }^{27}$ and libations. Choruses

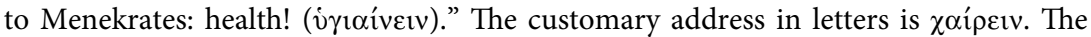

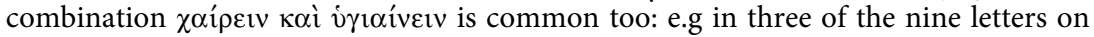
lead collected by D. Jordan, Hesperia 69 (2000) 91-103, espec. 91-92. The unique omission of the first word, however, must serve a semantic purpose. Note that Plut. Dem. 13 accuses the flatterers who proposed divine honours for Demetrios Poliorketes of "not irraiveıv." Thus íyıaiveıv suggests also 'be sane,' 'stop being insane.' Philippos had his own club of 60 gelotopoioi ('joke-writers', Athen. 14.614D-E) and was a great collector of jokes and joke books: J.N. Bremmer, Jokes, Jokers and Jokebooks in Ancient Greek Culture, in: J.N. Bremmer \& H. Roodenburg (edd.), A Cultural History of Humour. From Antiquity to the Present Day (Cambrige 1997) 11-28, espec. $15 \mathrm{f}$. In his turn, he was not safe from jocular derision either: H.S. Versnel, Philip II and Kynosarges, Mnemosyne 24 (1973) 273-279, but cf. Parker 2006, 257 with n.4.

${ }_{25}$ On Demetrios and Athens including his divine honours, see: G. Dimitrakos, Demetrios Poliorketes und Athen (Diss. Hamburg 1937); E. Manni, Demetrio Poliorcete (Rome 1952); Chr. Habicht, Athen. Die Geschichte der Stadt in hellenistischer Zeit (Munich 1995) 94-103; Mikalson 1998, 75-104; Parker 1996, 256-264. And see following footnotes.

${ }_{26}$ The entry of a king into a city belonged to the central elements of the ceremonies exhibiting his (divine) status, as we shall have occasion to observe throughout the present chapter. Strootman 2007, 'The ceremonial entry' pp. 289 ff. offers a good treatment with the main evidence. For the Roman period: J. Lehnen, Adventus principis: Untersuchungen zu Sinngehalt und Zeremoniell der Kaiserankunft in den Städten des Imperium Romanum (Frankfurt am Main 1997); A.-V. Pont, Rituals civiques (apantesis et acclamations) et gouverneurs à l'époque romaine en Asia Mineure, in: O. Hekster, S. Schmidt-Hofner \& Chr. Witschel (edd.), Ritual Dynamics and Religious Change in the Roman Empire: Proceedings of the Eighth Workshop of the International Network Impact of Empire (Heidelberg, July 5-7, 2007) (Leiden-Boston 2008) 185-211.

${ }_{27}$ This may have taken the shape of incense burning at little private altars cut from

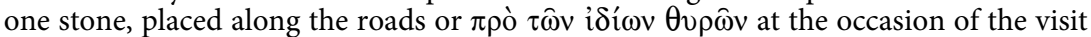
of a king or emperor, as they have been recovered in considerable numbers: L. Robert, Sur un décret d'Ilion et sur un papyrus concernant les cultes royaux, American Studies in Papyrology (Essays in Honour of B. Welles) I (1966) 175-211 = OMS 7 (1990) 599-635; F. Graf. Pedestals of the Gods, ZPE 141 (2002) $137 \mathrm{f}$. Note that in the famous inscription from Teos (SEG 41, 1003, II, 1l. 9-17 and 24-25) with regulations for the celebration of a festival for Antiochos III, every symmoria (civic subdivision) should set up an altar for the king and his sister and should bring sacrifice on this altar, while non-members of a symmoria "should sacrifice and celebrate in their own dwellings as 
danced and sang hymns to him. ${ }^{28}$ One of these hymns, made by the prize-winning poet Hermokles of Kyzikos, is handed down to us by Douris of Samos. ${ }^{29}$ The hymn must have enjoyed wide popularity, for, as Athenaeus 253F tells us, the Athenians sang the hymn not only in

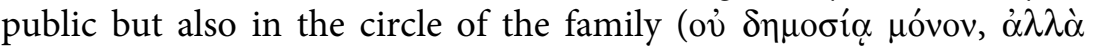

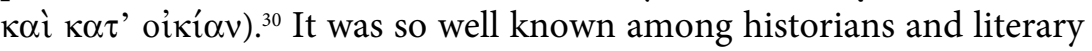
compilers that, besides the text as handed down by Douris, we also have summarizing references to it. ${ }^{31}$

I give here the aretalogical part of this oft-quoted hymn followed by the first lines of the prayer section. I have translated it as literally as possible while also trying to preserve a faint reflection of the metre, however awkward this may sound to our ears. ${ }^{32}$

See how the greatest and the most beloved gods

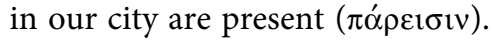

For here Demeter and Demetrios

one lucky moment (ó каıрós) brought us.

She has come to celebrate the holy

mysteries of Kore.

Joyous (i入 $\alpha \rho$ ós), as the god befits, beautiful and

laughing, he is present ( $\pi \dot{\alpha} \rho \varepsilon \sigma \tau \imath)$.

best as they can." On the honours assigned to Antiochos III at Theos see: Chaniotis 2007. Cf. the cultic regulations concerning the entry of Attalos III in Pergamon (OGIS 332) as discussed by P. Hamon, Les prêtres du culte royal dans la capitale des Attalides: note sur le décret de Pergame en l'honneur du roi Attale III (OGIS 332), Chiron 34 (2004) 169-185.

${ }^{28}$ As we will see he was neither the first nor the last to be honoured with hymns, paeans, epigrams. J.-D. Gauger, Der Rom-Hymnos der Melinno (Anth. Lyr. $\mathrm{II}^{2}$ 6, 209 f.) und die Vorstellung von der "Ewigkeit" Roms, Chiron 14 (1984) 267-299, espec. $267 \mathrm{n} .4$, gives a useful survey.

${ }_{29}$ Ap. Athen. 253F; J.U. Powell, Collectanea Alexandrina (Oxford $1925=$ Chicago 1981) 173 ff.; FGrH II A 76 Fr. 13, pp. 141 f.; Diehl. Anth. Lyr. Graec. 6 (1940) p. 104.

${ }^{30}$ Such a token of popularity, though not surprising, is rarely attested. Cf. Aristid. Or. 29.30, who tells us that songs from comedies recently performed were sung by everyone, including women and slaves, "in baths, in the alley-ways, in the marketplace, and at home."

${ }^{31}$ Demochares ap. Athen. 6.253BC $=F G r H 75$ Fr. 2 (II A, p. 134 f. no.2): including the phrase "the other gods are asleep, or are abroad or are not" (oi $\delta$ ' $\alpha \lambda \lambda \lambda_{01}[\theta \varepsilon o i]$

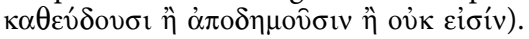

${ }^{32}$ To be frank, the literary quality of the Greek text is not particularly breathtaking either. Ehrenberg 1946, 180: "most certainly it is not a specimen of high poetry," at p. 181 referring to "its simplicity and humdrum triviality" and at p. 197 concluding: "Its unknown author is no great loss to literature." For more palatable, and certainly more poetical, translations the reader is referred to the literature collected in the following notes. However, practically without exception these translations are unacceptably free and, consequently, tend to smooth over the essential terms and concepts. 
An august ( $\sigma \varepsilon \mu v o ́ v)$ picture is revealed. All friends around him ${ }^{33}-$ and he is in the centre.

Just as the friends are like the stars, his semblance as the sun is.

$\mathrm{O}$ son of mighty god Poseidon and

Aphrodite, hail you!

Now, know that other gods are far away,

or have no ears or

don't exist or do not care about us.

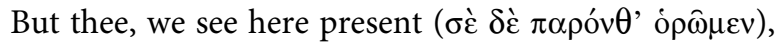
not wood, nor stone ( $\lambda \dot{i} \theta_{\text {ivov }}$ ) but real to the bone ( $\dot{\alpha} \lambda \eta \theta$ ivóv).

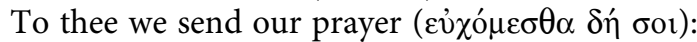

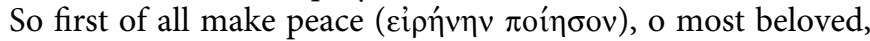

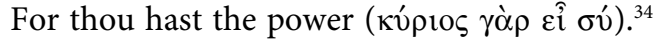

Easily a monograph, and an interesting one, could be written on this hymn with its display of a lavish collection of elements-both conceptual and terminological-characteristic of early Hellenistic religiosity. Indeed, numerous are the studies already devoted to this curious piece of literature..$^{35}$ Moreover, as one of the most unrestrained literary paroxysms of adoration of a ruler, it boasts pride of place in any study in the field of (early) ruler cult generally, and of Demetrios' deification in

${ }^{33}$ We have here, in a non-institutionalized form, a fore-runner of the more official philoi of the Hellenistic rulers, so well-known from literature (See e.g. Weber 1993, $23 \mathrm{ff}$.; 1995, $290 \mathrm{f}$. with full bibliography). However, circles of 'friends' round a prominent person of course occur much earlier: Empedokles had his retinue of philoi just like Menekrates, the early tyrants no less than the later ones like Dionysios I (H. Berve, Die Tyrannis bei den Griechen [Munich 1967], index s.v. Rat der Freunde), as well as the 'new politicians' of late 5th century Athens (W.R. Connor, The New Politicians of Fifth-century Athens [Princeton 1971] 26 ff.; 71 ff.; 129-132). One of Demetrios' 'friends', Adeimantos, has acquired more 'body' due to a letter of his to Demetrios, found in an inscription at Delphi: L. Robert, Hellenica II (1946) 15-33. The same Adeimantos also founded an altar for Phila Aphrodite, one of the wives of Demetrios, on which see: Carney 2000, 169 f.; 209-225. Like the followers of Menekrates, some friends of Demetrios acquired heroic honors: Mikalson 1998, 88.

${ }^{34}$ Next follows a twelve-line prayer with the request to defeat and punish the Aetolian pirates.

35 O. Weinreich, Antikes Gottmenschentum, Neue Jahrb. 2 (1926) 633-651, espec. 646-649; K. Scott, The Deification of Demetrius Poliorcetes, AJPh 49 (1928) 217-239, espec. 228-236; V. Ehrenberg, Athenischer Hymnus auf Demetrios Poliorketes, Antike 7 (1931) 279-297 = idem, Aspects of the Ancient World: Essays and Reviews (Oxford 1946) 179-198; L. Alfonsi, Sull" "Itifallo" di Ermippo, RhM 106 (1963) 161-164; Marcovich 1988; Bergmann 1997; Kolde 2003, 378-389, who considers the possibility that the Ithyphallos may have influenced the Hymn of Isyllos, which she dates to the period of the Celtic invasion. Neither supposition impresses me as very likely. 
particular. ${ }^{36}$ Comments by scholars of an earlier generation illustrate modern embarrassment in an exemplary way. ${ }^{37}$

At this point we must restrict ourselves to a brief list of the most conspicuous religious motifs in the hymn: ${ }^{38}$

- The parousia of the new gods as apparent from the prominence of the

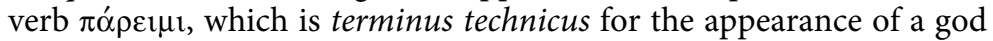
in epiphany-stories, as are the elements of beauty and laughter, as well as the term i $\lambda \alpha \rho^{\prime} \varsigma^{, 39}$

- the assimilating wordplay on Demeter-Demetrios. As the goddess came on her wanderings to Eleusis to the glorification of Athens, and

\footnotetext{
${ }^{36}$ Just a few: O. Immisch, Zum antiken Herrscherkult, in: Aus Roms Zeitwende: Vom Wesen und Wirken des Augusteischen Geistes (Das Erbe der Alten 20, 1931) 6-12; W. Schubart, Die religiöse Haltung des frühen Hellenismus (Der alte Orient 35.2, 1937) 18 f.; Nilsson, GGR II 151 ff.; E. Manni. o.c. (above n. 25) 93 ff.; Dodds 1951, 241 f.; Cerfaux-Tondriau 1957, 181-187; Taeger 1957, I 270-273; Cl. Wehrli, Antigone et Démétrios (Genève 1968) 177 f.; Habicht 1970, 232 ff.; L. Kertész, Bemerkungen zum Kult des Demetrios Poliorketes, Oikumene 2 (1978) 163-175 (emphasis on military nature of the cult and the special link between father Antigonos and his son); idem, Religionsgeschichtliche Voraussetzungen zur Herausbildung des Herrscherkultes in Athen, Oikumene 4 (1983) 61-69; I. Mastrocinque, I miti della sovranità e il culto dei Diadochi, Atti dell' Istituto Veneto, Cl. sc. morali, lettere ed arti 137 (1978-9) 71-78; F. Landucci Gattinoni, La divinizzazione di Demetrio e la coscienza ateniese, Contributi dell' Istituto di Storia antica dell' Università del Sacro Cuore 7 (1981) 115-123; G. Sommariva, Il proemio del De rerum natura di Lucrezio e l'inno a Demetrio Poliorcete, SIFC 54 (1982) 166-185; A.W. Bulloch, The Future of a Hellenistic Illusion: Some observations on Callimachus and religion, MH 41 (1984) 209-230 (taking the hymn as point of departure for an enquiry into religion in Hellenistic poetry); Weber 1995, espec. 303 ff.; Mikalson 1998, Ch. 3 "Twenty Years of the Divine Demetrios Poliorcetes", espec. 94-97; Chaniotis 2003a, espec. $431 \mathrm{ff}$., an excellent brief introduction to the essential constituents of Hellenistic ruler cult, with a valuable bibliography; Kolde 2003, 364-392; Chaniotis 2011.

${ }^{37}$ Immisch, o.c. (preceding note) $6 \mathrm{f}$.: "Es ist religionsgeschichtlich von großer Wichtigkeit, weil es-in fast erschütternder Weise-dartut, wie völlig eine Religiosität der Immanenz sich schließlisch verflüchtigt in bloße Symbolik;" Nilsson GGR II, 152: "Weiter konnte man nicht gehen und ist man nie gegangen;" Taeger 1957, I 278: "Demetrios hat... als erster unter den Königen die letzte Schranke niedergelegt und seine Gleichheit mit den grossen Göttern aller Welt programmatisch verkündet."

${ }^{38}$ Weinreich 1926 was the first to collect them and give a running commentary which, like every publication of this great scholar, has lost nothing of its interest; Scott 1928 offered an English rendering of Weinreich's survey, Ehrenberg 1931 a good discussion, and Cerfaux-Tondriau 1957 again a discussion of the various elements. Most recently see: Bergmann 1997. I give here only the ones most illustrative of the religious nature of the hymn. Chaniotis 2011 offers a new thorough treatment.

${ }^{39}$ Keyssner 1932, $130 \mathrm{ff}$. presents the testimonia of divine joy and laughter, with reference to Demetrios.
} 
continues attending her mysteries, so now has Demetrios come to save the city, ${ }^{40}$

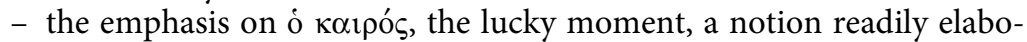
rated in Christian theology, ${ }^{41}$

- the symbolism of sun and stars, extremely popular in ruler ideology from the Hellenistic period ${ }^{42}$ into the Middle Ages and early modern

${ }^{40} \mathrm{I}$ here avoid being entangled in the neverending discussion concerning the identity of this Demeter, who is often identified with Lanassa, the fourth wife of Demetrios. If so, she must have been dressed up as Demeter. Against the necessity of Lanassa's participation Marcovich 1988, 11, refers to the Athenian decree of 294 BC (as transmitted by Plutarch Demetr. 12.1), which reads: "Whenever Demetrios visits the city he shall be received with the honours usually paid to either Demeter or Dionysos." Against its probability there is a testimony by Demetrios' contemporary Demochares ap. Athen. 6.253B, that Demetrios, after his wedding with Lanassa on the island of Corcyra, returned to Athens alone. The fact that Demetrios arrived at Athens at the moment when the Athenians were about to celebrate the mysteries may suffice to explain Demeter's appearance in the hymn. She may-but need not-have been represented in the form of a statue. On Demeter's advent as an epiphany, see: H. Metzger, Recherches sur l'imagerie Athénienne (Paris 1965) 10. Irrespective of the form in which she was deemed present, real or in the mind, she may have been conceived of as the divine consort or patroness of the king. This, then, calls to mind Peisistratos' entry at Athens accompanied by the handsome Phue/Athena, on which: R.H. Sinos, Divine Selection: Epiphany and Politics in Archaic Greece, in: C. Dougherty \& L. Kurke (edd.), Cultural Poetics in Archaic Greece (Cambridge 1992) 73-91; J.H. Blok, Phue's Procession: Culture, Politics and Peisistratid Rule, in: H. SancisiWeerdenburg (ed.), Peisistratos and the Tyranny: A Reappraisal of the Evidence (Amsterdam 2000) 17-48; N. Robertson, Athena as Weather Goddess, in: S. Deacy \& A. Villing (edd.), Athena in the Classical World (Leiden 2001) 29-56, espec. 36; L. Llewellyn-Jones, Sexy Athena. The Dress and Erotic Representation of a Virgin War-Goddess, ibid. 233-257, espec. 244 with n.25. Noteworthy that there, too, the public received the goddess with prayer: Hdt. 1.60. "being convinced that the woman

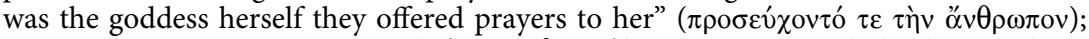

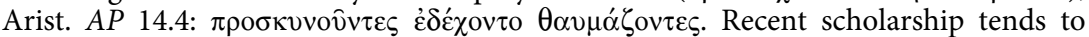
accept the authenticity of the belief in her divinity. With her qualification of 'heroic illusion' Sinos comes close to the appreciation of ruler cult that I will defend below.

${ }^{41}$ For the Greek development of the term (not including its occurrence in the Ithyphallos) see: M. Frédé, Kairos: L'à-propos et l'occasion (Le mot et la notion d'Homère à la fin du IV siècle avant J.-C.) (Paris 1992).

${ }_{42}$ The closest parallel is Hor. Sat. 1.7.24: laudat Brutum laudatque cohortem, solem Asiae Brutum adpellat stellasque salubris adpellat comites. On the Sun as "der höchste Vergleichsgegenstand in der Chorlyrik" in general: M. Puelma, Die Selbstbeschreibung des Chores im Alkmans grossem Partheneion-Fragment, MH 34 (1977) 1-55, espec. 7-19 (here: $14 \mathrm{n}$. 33), inter alia quoting Anacreon's acclamation to the Sun (Fr.

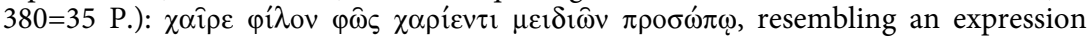
in the Demetrios hymn. Kingship as reflection of the sun: E.R. Goodenough, The Political Philosophy of Hellenistic Kingship, YClSt 1 (1928) 55-102, espec. 78-83. Rulers identified, compared with or accompanied by the sun: W.W. Tarn, Alexander Helios and the Golden Age, JRS 22 (1932) 135-160; A.D. Nock, The Emperor's Divine Comes, JRS 37 (1947) 102-116, espec. 114 ff. = idem 1972, 672-675; Weinstock 1971, 381-384. Rulers and stars: ibid. 375-381. Similes with the Sun especially in Roman adventus descriptions: S. MacCormack, Change and Continuity in Late Antiquity. 
Europe. We know from other sources (Douris ap. Athen. 12.535F; Plut. Demetr. 41.6) that, like other Hellenistic rulers, ${ }^{43}$ Demetrios went dressed in a robe adorned with suns and stars, as did le roi-soleil, ${ }^{44}$

- his divine parentage in the gods Poseidon and Aphrodite, ${ }^{45}$

- the emphasis on Demetrios' quality of 'present god' (note that this is the third time that the verb $\pi \alpha$ ó $\varepsilon \_\mu$ turns up) ${ }^{46}$ who can be seen, ${ }^{47}$ unlike the traditional gods, who, with "fourth-century scepticism" (Scott 1928) are censured for their absenteism ("far away"), for not hearing (i.e. not being غं $\pi \dot{\eta} \kappa o o \imath),{ }^{48}$ not caring, and who are even

The Ceremony of Adventus, Historia 21 (1972) 730-733, and in eisiteria (arrivals of governors): Pfister, Epiphanie, RE Suppl. IV (1924) col. 304. Comparable imagery of stars at arrival of prominent people: L. Radermacher, Aristophanes' Frösche (Graz etc. 1967) on 1. 342, p. $188 \mathrm{f}$. Menander Rhetor 2.3.378, even spells out the precise

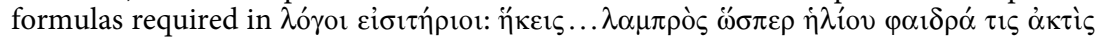
óv $\omega \theta \varepsilon v \dot{\eta} \mu \hat{i} v$ ó $\varphi \theta \varepsilon i \sigma \alpha$ ("you come brilliant as a ray of the sun that appears to us on high"). Helios naturally is the greatest or the king of the heavenly gods: W. Fauth, Helios Megistos. Zur synkretistischen Theologie der Spätantike (Leiden 1995), espec. xxii ff., but flourished in this position in the Hermetic writings: Fauth, ibid. xxx ff.; $\mathrm{CH}$ 5.3, with the learned note of Nock-Festugiere in the Budé edition of the Corpus Hermeticum I, p. 65, n. 10; Demetrios of Phaleron was praised as $\dot{\eta} \lambda$ ió $\mu$ op $\varphi$ os in a hymn (Douris ap. Athen. 12.542E = FgrH 76 Fr. 10). Note that Demetrios's solar status in the ithyphallos anticipates the emphasis on his visibility later in the hymn:

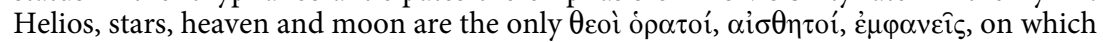
see extensively: J. Kroll, Die Lehren des Hermes Trismegistos (Münster 1914) 98-110. On rulers pictured with solar and astrals symbols: M. Bergmann, Die Strahlen der Herrscher: Theomorphes Herrscherbild und politische Symbolik im Hellenismus und in der römischen Kaiserzeit (Mainz 1998); with divine attributes in general: D. Svenson, Darstellungen hellenistischer Könige mit Götterattributen (Frankfurt 1995); Kolde 2003, 372-377.

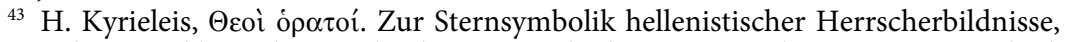
in: Studien zur klassischen Archäologie, Festschrift zum 60. Geburtstag von Friedrich Hiller (Saarbrücken 1986) $55 \mathrm{ff}$.

${ }^{44}$ P. Burke, The Fabrication of Louis XIV (Yale Univ. Pr. 1992). See on this aspect in the hymn most recently: Bergmann 1997.

${ }^{45}$ The choice of Poseidon as his father is no surprise since Demetrios as master of the seas had a clear preference for the god on his coins, while the lineage with Aphrodite may be either due to his four marriages as is often surmised, or to his exceptional beauty (Plut. Demetr. 2.2) or both: hardly as a reference to the marine Aphrodite Euploia (Bulloch o.c. above n. 36, 210), however popular she may have been. Note that the establishment of cults for royal wives and hetaerae was closely connected with their assimilation with Aphrodite: Carney 2000, 218-225.

46 'Presence' is a ubiquitous element in ruler cult. See i.a.: F. Mitthof, ZPE 99 (1993) 97-111; M. Clauss, Deus Praesens. Der römische Kaiser als Gott, Klio 78 (1996) 400433; idem 2001, $263 \mathrm{f}$. on the omnipresence of the divine emperor; C. Ando, Imperial Ideology and Provincial Loyalty in the Roman Empire (Berkeley and Los Angeles 2000) 232-253; idem 2008, 118 f. Cf. Chaniotis 2011, 106-111.

${ }^{47}$ The importance of visibility (epiphaneia) in divine presence is underlined by Chaniotis 2003a, 431. Cf. also Chaniotis 2011, 107; 110; 114.

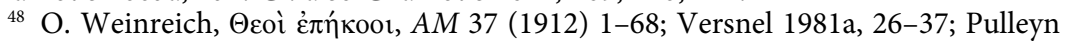
1997, 134-144, on verbs of hearing and verbs of coming in prayer. 
suspected of not existing-arguments whose Epicurean flavour has not gone unnoticed, ${ }^{49}$

- consequently, the old gods only exist in the shape of their wooden or stone images, while Demetrios is 'real', a contrast well-known from later philosophical and Christian apologetic literature, ${ }^{50}$

- consequently, too, it is appropriate to pray to the god,

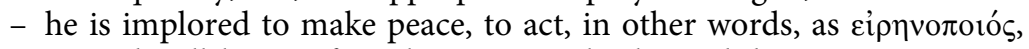
a word well-known from later imperial titles and the New Testament, which puts him on a par with soter-gods,

49 Which is not equal to claiming direct Epicurean influences. "Il Poliorceto è un vero dio epicureo, così come deus vero sarà Epicuro stesso per i suoi seguaci (Lucr. V.8: deus ille fuit, deus...)" represents one extreme position, as taken by Alfonsi o.c. above n. 35, 164. Cf. Cerfaux-Tondriau 1957, 185: "les théories d'Épicure ont touché les couches populaires." The Epicurean influence is most extensively discussed and defended by Marcovich 1988, 13-17. On the Epicurean 'philosophical religion' see recently: R. Koch, Comment peut-on être dieu? La secte d'Épicure (Paris 2005). Others prefer a more general influence of fourth century 'Popularphilosophie.' Kritias' Sisyphus 17-21, and particularly Plato Leg. 10.885b, contain similar expressions: "No

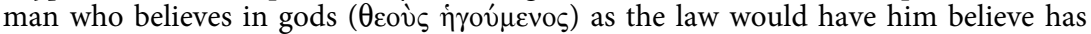
ever yet of his own free will done unhallowed deed or let slip lawless discourse. If a man acts thus, it is from one of three causes. Either, as I say, he does not believe (ov่ $\chi$

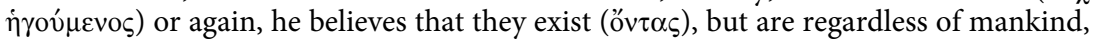
or lastly that they are lightly to be won over by the cajoling of offerings and prayers" (tr. A.E. Taylor). Cf. ibid. 889a-890a. They lack, however, the notion that the gods are far away from men, the latter of which, of course, comes closest to the Epicurean position. The identity of these 'atheists' is the object of much controversy. See e.g.: J. Tate, On Plato: Laws X 889CD, CQ 30 (1936) 48-54; Guthrie 1969, III 115 f.; W. de Mahieu, La doctrine des Athées au X $\mathrm{X}^{\mathrm{e}}$ livre des Lois de Platon, RBPh 41 (1963) 5-24 and 42 (1964) 16-47. From 306 BC onwards Epicurus had taught in Athens. Yet, even this does not unequivocally prove that Epicurean ideas had served as a model: below we will discuss a solid late 5th century literary parallel of distant gods, which as far a I know, has not been noticed so far.

${ }^{50}$ The word-group $\dot{\alpha} \lambda \dot{\eta} \theta \varepsilon \imath \alpha, \dot{\alpha} \lambda \eta \theta \hat{\eta} \varsigma, \dot{\alpha} \lambda \eta \theta v v o ́ s$, acquires an emphatically contrastive connotation in NT and early Christian writings: TWNT 1 (1933) s.v. Cf. also Psalm 115, 4 ff. "Their (i.e. the heathens') idols are silver and gold, the work of men's hands. They have mouths but they speak not: eyes have they but they see not. They have ears, but they hear not; noses have they but they smell not. They have hands but they handle not; feet have they but they walk not; neither speak they through their throat. They that make them are like unto them." Val. Max. Praef. "While eminent poets opened their works with an invocation of a divine power (a numine aliquo) I call in your benevolence ( $v i z$ of emperor Tiberius), with more right because the divinity of the others is based on opinion (opinione colligitur), while yours manifests itself by a visible testimony ( praesenti fide videtur).... Other gods we have received from tradition, but the Caesares we have bestowed [i.e. as Rome's contribution to the [divine?] world]" (Deos enim reliquos accepimus, Caesares dedimus). Ovid, Ep. Pont. 2.8.57 f. envies those who do not have to be satisfied with images of gods, but, being able to see the emperor, can behold them in person: felices illi, qui non simulacra, sed ipsos, quique deum coram corpora vera vident. Divine images appearing in dreams, on the other hand, equal real gods, according to Artemidorus (testimonia in Weinreich 1909, 158). See for important inferences of this distinction: Chaniotis 2011, $110 \mathrm{f}$. 
- D. is kurios, a term whose (monozygotic) twin connotations have not always been sufficiently validated: while kurios generally denotes 'master' or 'lord', as in the later emperor cult and Christology, the

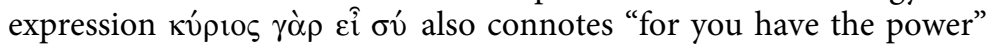
in terms of being the only one capable of rescuing the Athenians and destroying the enemy. ${ }^{51}$

Demetrios boasted a great number of divine honours, most of them granted by the Athenians, others just his own creations. ${ }^{52}$ In $307 \mathrm{BC}$ father Antigonos and son Demetrios were hailed by the Athenians as ( $\Theta \varepsilon \circ i) \Sigma \omega \tau \hat{\eta} \rho \varepsilon \varsigma^{53}$ and in this quality received an altar and a priest ${ }^{54}$ while henceforth consistently being referred to as $\Sigma \omega \tau \hat{\eta} \rho \varepsilon \varsigma$ in inscriptions. Two tribes, Demetrias and Antigonis, were added to the existing

${ }^{51}$ This semantic doubleness is an ideal metaphor of the 'poetics' of ruler cult. While Habicht like many others singles out concrete and actual achievements of a ruler as the essential motive for founding a cult (cf. P. Green, Delivering the Go(o)ds: Demetrios Poliorketes and Hellenistic Divine Kingship, in: G.W. Bakewell \& J.P. Sickinger [edd.], Gestures. Essays in Ancient History, Literature, and Philosophy Presented to Alan L. Boegehold [Oxford 2003] 258-277), scholars of an earlier generation (as for instance Nock) focussed on the superior status and inherent qualities of the ruler. Nor should one confuse initial cause and cultic perseverance. Even if initially inspired by a single act of liberation (as it often was), once established the cult concerned a god with the concomitant superior qualities, whose ongoing task was the same as that of

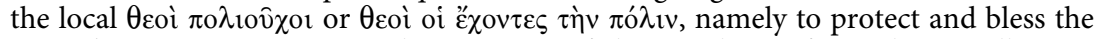
city. These twin notions are characteristic of the aretalogies for gods in Hellenistic and imperial times as we have seen in Ch. III. An inscription from Rhamnous for an Antigonos, most probably Gonatas (V. Petrakos, Praktika Arch. Hetairias $144(1989$ [1991]) 1-37, no. 15; BE 94, 299) provides a beautiful illustration. The people honours

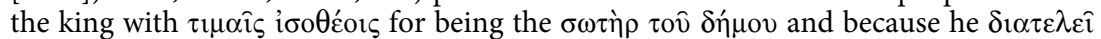

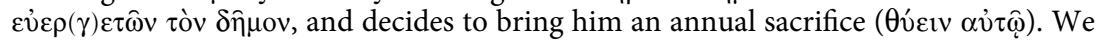
are close here to 'proleptic honours' as discussed by M.D. Gygax, Proleptic Honours in Greek Euergetism, Chiron 39 (2009) 163-191. Cf. Parker 1996, 260 and Chaniotis 2003a, 432 concluding: "What places the kings on the same level with the gods is the protection they offer." More generally, the festivities at the arrival of a Hellenistic or Roman ruler in Greek cities (known as apantêsis) should be interpreted as tokens of both gratitude for and expectation of beneficies: É. Perrin-Saminadayar, L'accueil officiel des souverains et des princes à Athènes à l'époque hellénistique, $B C H$ 128-129 (2004-2005) 351-375.

${ }^{52}$ I mention only the most conspicuous ones; for all details and the sources see the literature in n.35 and n.36, especially Scott, Taeger, Cerfaux-Tondriau, Habicht, Mikalson, and most recently with a focus on Demetrios' own initiatives: Thonemann 2005 and Kuhn 2006.

${ }^{53}$ In the inscriptions of that period they are not explicitly referred to as theoi (Habicht 1970, 44 n. 2), though as Soteres they were, indisputably, viewed as gods (Habicht 1970, 157; Mikalson 1998, 80).

${ }_{54}$ B. Dreyer, The Hiereus of the Soteres: Plut. Dem. 10.4, 46.2, GRBS 39 (1998) 23-38. In 311 the Skeptians had anticipated this by awarding Antigonos and his sons a temenos, altar, statue (note: not an image), sacrifices, games, and an annual panegyris (OGIS 6, espec. 1l. 20-33). See espec. Habicht 1970, 42 ff. 
ten tribes, and, accordingly, the two rulers acquired the status of phylai gods ${ }^{55}$ Simultaneously with these honours, the Athenians, first of the Greeks, proclaimed Demetrios 'King' (Plut. Demetr. 10.3). ${ }^{56}$ In 304, at

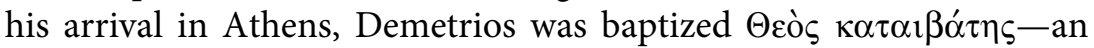
epithet, like soter, usually associated with Zeus in particular-connoting the sudden appearance of a god among humans. An altar for the 'descending' god was erected at the spot where he had left his carriage when he entered Athens for the first time. It should be noted that the divine identifications as Soter, eponymous phyle-god and Kataibates, all three profusely furnished with cultic apparatus, referred to totally different gods, a remarkable type of accumulation that we also find in the hymn.

The Athenians assigned the new god part of the Parthenon (the opisthodomos) as housing, ${ }^{57}$ where he entertained a bevy of hetaerai referred to by Plutarch as whores ( $\pi$ ópval): "eine Orgie schamloser Asebie" (v. Wilamowitz 1931, II 268). A sacred marriage with Athena, whom Demetrios used to call "his elder sister," may have been considered..$^{58}$ In 294 the people took a decree ${ }^{59}$ stipulating that "whenever Demetrios visits the city he shall be received with the honoursincluding theoxenia-usually paid to either Demeter or Dionysos."

${ }^{55}$ Note that they did not become tribe heroes like the other ten eponyms, but remained gods.

56 Utopias require kings: Versnel 1993, 201; 206, and on Kronos, the first utopian king: ibid. 95-99. Cf. Mikalson 1998, 83: "If, as I have claimed (Mikalson 1991, 196201), the model for human piety towards the gods was the relationship of a subject to his king, it may not be coincidental that the Athenians, first of the Greeks and simultaneously with these divine honours, proclaimed Demetrios 'king' (Plut. Dem. 10.3). Certainly not consciously (...) the Athenians were fitting Demetrios into a model that would allow them to give him divine honours."

${ }^{57}$ See Kuhn 2006, 272-275. In 306, at Delos, Demetrios was temporarily accommodated in the tempel of Apollo. Like his irregular initiation in the Eleusinian mysteries this blasphemy did not remain without criticism: "He who compressed the year to a single month, who treated the Acropolis as a tavern and introduced the call-girls to the maiden. (.....) This is what subverts democracy, not comedy," thus Philippides Fr. $25 \mathrm{~K} / \mathrm{A}$ (cf. below n. 92).

58 "But he disdained the goddess since he could not marry her statue" (Clem. Al. Protr. 4.54.6). Scheer 2000, 271-279, espec. 277-279, discusses and rejects the historicity of the marriage between the king and the statue of Athena. However, courting a goddess, especially Athena, is a topos in Hellenistic ruler ideology: Rhianos (o.c. below n. 120). Cf. Kotus of Thracia as described by Theopompos (Athen 12.531F; FGrH 115 fr. 31).

${ }^{59}$ For this decree as transmitted by Plutarch Demetr. 12.1-12.2, see: W.S. Ferguson, Demetrius Poliorcetes and the Hellenic League, Hesperia 17 (1948) 112-136, espec. 131 n.43, and FGrH 328, F. 166, p. 542 f. 
Demetrieia (festivals for Demetrios) were established and are also reported for several other cities in Greece. They were framed on the model of the Dionysia, indeed to such an extent that some later authors understood that the Athenians had turned their Dionysia into Demetrieia. $^{60}$

Among numerous other features illuminating the religious atmosphere of early Hellenistic culture, there is one that may help us, if not to understand, yet at least to become more familiar with the true nature of the phenomenon that I will call 'playing the god'. Interpreters of the Ithyphallos have often surmised that Demetrios in the divine epiphany of the first lines personalizes Dionysos, as, in other contexts as well, the king displayed marked Dionysiac traits. ${ }^{61}$ Yet Demetrios is not Dionysos, since he is referred to by his own name. The hymn also closely associates him with Demeter. ${ }^{62}$ Yet he is not her spouse, which would make him another Zeus or Poseidon. He is also compared with the Sun, but this does not make him god Helios ${ }^{63} \mathrm{He}$ is addressed as son of Aphrodite and Poseidon, without being that in the literal sense

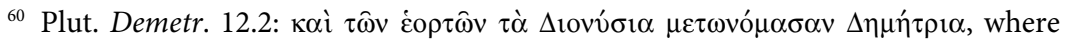
some scholars try to save Plutarch by rectifying the text into $\mu \varepsilon \tau \omega v o ́ \mu \alpha \sigma \alpha v<\Delta$ tovv́ $\sigma 1 \alpha$ $\kappa \alpha \grave{\imath} \Delta \eta \mu \eta \dot{\tau} \tau 1 \alpha$. Anyway, such a rebaptizing cannot be historical since Dionysia continued to be recorded and in one inscription Demetria and Dionysia appear together. Cf. Habicht 1970, 53 ff., espec. 53: "Dionysien und Demetrien sind vielmehr ein einheitliches Fest mit doppeltem Namen gewesen." See especially the thorough discussion by Thonemann 2005, 78-81, who argues that the Demetrieia were a theatrical re-enactment of Demetrios' entry in Athens in 296/5, as an imitation of the Dionysia which re-enacted Dionysos' arrival in Athens. Recently on the Dionysiac aspects of Demetrios: Chaniotis 2011, 100-114 and on Dionysiac elements in the honoring of Antiochos III at Teos: Chaniotis 2003b.

${ }^{61}$ Among others Kolde 2003, 385, who after others argues that 1l. 7-8 certainly describe him as the god Dionysos. Of course, the genre ithyphall(ik)os is typically Dionysiac. Think also of the Dionysia "replaced" (see preceding note) by the Demetria, in which the Dionysiac technitai-the professional actors-took an important part. For further details see Cerfaux-Tondriau 1957, $180 \mathrm{f}$. and especially Chaniotis in his two studies cited in the preceding footnote. On the special preference of the Antigonids for Dionysos, as well as on Hellenistic rulers' assimilation with gods, see: R. Thomas, Eine postume Statuette Ptolemaios' IV und ihr historische Kontext. Zur Götterangleichung hellenistischer Herscher (Mainz 2002).

${ }^{62}$ While the goddess comes to celebrate $\tau \grave{\alpha} \sigma \varepsilon \mu v \grave{\alpha} \mu \nu \sigma \tau \dot{\eta} \rho 1 \alpha$ the god Demetrios represents a $\sigma \varepsilon \mu v o ́ v \tau$ l. The word semnos is characteristic of Demeter and her cult.

${ }^{63}$ Which-just as an aside-would unbearably complicate familial affiliations: his father Antigonos had already been referred to as "son of the Sun" ("H $\lambda$ íov $\pi \alpha \hat{\imath} \delta \alpha$ ) and

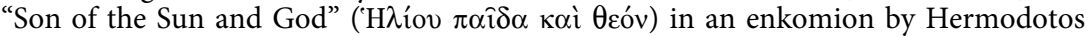
(Plut. Mor. 182C; 360C).
} 
of the word which would make him either another Aeneas or another Polyphemos respectively. ${ }^{64}$

This alarmingly naive and indeed bluntly reductionist phrasing of the problems inherent in the accumulation of divine associations is, I hasten to say, intentional. I thus hope to demonstrate that, if taken literally-and hence scrutinized in terms of its (mythological) coherence, implications and consequences-the hymn would convey a desperately chaotic and inconsistent picture. To avoid this chaos, I would once more-as in our first chapter (and in most others) - suggest that we not do this; in other words neither extend the different associations to the total gamut of their conventional mythological implications (since this is not their intended function in the hymn), nor interconnect the different statements. They are hints, flashes, evoking temporary roles, and thus metaphorically prompting different qualities and virtues of the object of praise. Each virtue can - and should-be stored in the mind of the reader (or singer) in order to be accumulated into an all-encompassing image of bliss, whereas each individual role, after having delivered its message, can-and must-be discarded, to make place for the next one. Viewed together-all remaining active in the consciousness of the reader-the roles would yield a mess. Taken successively, hence separately, they yield a message. ${ }^{65}$ Viewed in this way

${ }^{64}$ As so often, it was A.D. Nock, who already in 1930, in his ground-breaking article $\Sigma$ YNNAO $\Sigma \Theta$ EOS (= Nock 1972, 202-251) elucidated these and other essential distinctions: "But it is essential that we should understand that what sounds like formal identification is often only a kind of association or comparison" (ibid. 235), where my only suggestion would be to change "only" into "actually."

${ }^{65}$ See Gauger 1984, 268, who among the different divine associations in the Ithyphallos distinguishes successively: 1) "suggestive Zusammenstellung von Gott und Mensch (Demetrios und Demeter)"; 2) "Zuschreibung göttlicher Attribute"; 3) "kosmischer Vergleich" (Helios); 4) "mythologische Neukonstruktion" (Sohn des Poseidon und Aphrodite)". Also Weber 1995, 304: "Er enthält einerseits eine Parallelisierung des Demetrios mit Demeter, eine Darstellung als Dionysos und die Anrede als Sohn von Poseidon und Aphrodite" (my italics). Very to the point Bergmann 1997, 40, discussing the Hellenistic imagery of rulers displaying an accumulation of attributes that belong to several different gods: "Die Attribute müssen einzeln gelesen werden," (my italics) and referring to the analogy with the at first sight confusing affiliation of Demetrios with both Poseidon and Aphrodite: "Wenn (...) die Filiationen einzeln gelesen werden müssen und auf Eigenschaften des Königs hinweisen, die im Bereich dieser Götter angesiedelt sind, dann ist diese Akklamation das verbale Gegenstück zu den Herrscherbildnissen mit den kumulierten Attributen der Göttern." Cf. also P. van Nuffelen, Le culte des souverains hellénistiques, AncSoc 29 (1998-1999) 175-189, on the essential role of the associations of kings with gods. 
the hymn may make an important contribution to the central issue of this chapter concerning the problems evoked by ruler cult.

I will postpone a brief discussion of the risks inherent in comparison on the one hand and of the application of logical reasoning on religious issues on the other till later in this chapter. But this is the right moment to refer to an important observation concerning allegory and personification, made by Barbara Borg 2002, $311 \mathrm{ff}$., which is relevant to the questions of allegorical interpretation that we just discussed. She argues that with respect to the allegorical structure of images as well as to their message it is immaterial whether personifications are conceived of as poetical fictions or as divine figures. Just as in archaic and classical times the categories '(historical) fact' and 'fiction' were not essential for the assessment of the 'value' of a narrative, so, too, in visual art the fictionality of the representation is not seminal to the appraisal of the degree of its truthfulness. ${ }^{66}$ And she adds (313):

In addition, the semantic fuzziness of visual representations allows each individual 'reader' a scope for inspiration (within the limits set by the 'rhetorical' strategy) that surely contributed to the attractiveness of the images as well, and that also lent them a potential for a range of meanings, which could be covered only ponderously and with difficulty by abstract verbal discourse (my italics).

The italicized part in particular seems to me to be relevant to the ways in which the divinity of the ruler was moulded in word and act.

Two new gods on the brink of the Hellenistic period, a doctor and a king. They were preceded by some and succeeded by many others. It has often been argued that in this period rulers took over the niche that was left vacant by the fading gods. Here is Dodds' $(1951,242)$ comment on the Demetrios hymn:

When the old gods withdraw, the empty thrones cry out for a successor, and with good management, or even without management, almost any perishable bag of bones may be hoisted into the vacant seat.

This point of view raises all kinds of questions-which I will not broach-but also provoked, or was inspired by, the fatally misconceived

${ }^{66}$ Cf. C. Gill, Plato on Falsehood-non Fiction, in: C. Gill \& T.P. Wiseman (edd.), Lies and Fiction in the Ancient World (Exeter 1993) 38-87. Recent work on personification: E. Stanford \& J. Herrin (edd.), Personification in the Greek World: From Antiquity to Byzantium (Aldershot 200). I thank the author for the English translation of her German text, that she made on my request. 
sceptical assessment of Greek ruler-cult which dominated the greater part of the twentieth century debate. And this in fact directly concerns our present issue.

\section{Modern Perplexities}

That Greeks could have deified and worshipped human beings-even if they were kings-was a skandalon to (most) classicists of the first half of the last century. The divine Nilsson in his still indispensable masterpiece on Greek religion (GGR II, 153) qualified the Hellenistic epoch as "die Periode des tiefsten Verfalls der Religion und der schlimmsten Orgien des Menschenkultes" (the period of the vilest decay of religion and of the most abominable orgies of the cult of mortals), and G. Murray ${ }^{67}$ in his widely read "Five Stages of Greek Religion" for this very reason gave his chapter on Hellenistic Religion the title: 'The Failure of Nerve', in which he was followed by Dodds whose Hellenistic chapter in "The Greeks and the Irrational" was entitled: 'Fear of Freedom'. Nilsson and Murray were pre-war gentlemen and, as gentlemen, were disappointed in the regrettable behaviour of their Greeks. Yet, indignation presupposes at least the recognition of the reality censured. Others could not even admit as much.

One strategy to get rid of irritating evidence is to explain it away. How far scholars may be prepared to go can be demonstrated by a notorious and most illuminative case, viz. the manipulation of the evidence concerning one of the earliest attestations of divine honours for a ruler, the Spartan admiral Lysander, 'liberator' of Athens' last ally, Samos, in 404 BC. A century later, the historian Douris-himself an inhabitant of that island-relates that the grateful Samians erected an altar for Lysander, honoured him with sacrifices, agones and paeans and renamed the great games in honour of Hera as Lysandreia. Particularly those scholars who blamed the abomination of ruler-cult on Oriental influences ${ }^{68}$ after Alexander, performed miracles in their

${ }^{67}$ On this scholar: Chr. Stray (ed.), Gilbert Murray Reassessed. Hellenism, Theatre, and International Politics (Oxford 2007), in particular Robert Parker's contribution on the writings of Greek Religion, pp. 81-102.

${ }^{68}$ Especially Taeger, whose undisguised racist interpretations-e.g. "hier wie dort hat der fremde Blutzustrom die religiöse Haltung tief beeinflusst"-was duly put to the sword by Habicht 1970, 274 f. Nevertheless, P. Cartledge, Agesilaus and the Crisis of Sparta (Baltimore 1987) 82-86, still attributes this first cultic deification of a living 
attempts to smooth away this evidence. First, Douris "ist notorisch nicht ganz zuverlässig" and, secondly, an event so shocking as the rebaptizing of Heraia into Lysandreia, if historical, would no doubt have been mentioned in other ancient sources too. Perhaps a statue of Lysander, carried along in the festive procession, had enticed Douris into his false interpretation. Or, perhaps an Athenian comedy writer had made a joke: "the Samians have changed their Heraia into Lysandreia", and the irony was taken as historical fact by-again - bête noire Douris. No less a scholar than A.D. Nock accepted this suggestion. It is the great merit of Chr. Habicht to have refuted all these arguments one after the other, concluding that there was no objective reason whatever to distrust the evidence concerning the divine honours for Lysander. He did this in the first edition of his Gottmenschentum und Griechische Städte. ${ }^{69}$ Eight years later, in 1964, an inscription was found on Samos

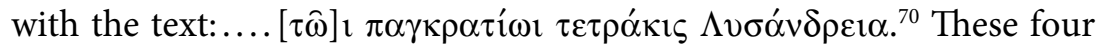
words irrefutably prove, first, that the Lysandreia were not a comic invention, secondly, that they must have taken the place of the older Heraia, or may have been added to them and indeed have existed for at least four years, and, thirdly, that on this particular point Douris was correct, so that there is no reason anymore to distrust, without conclusive arguments, his other assertions. Quite another question, of course, is, whether Lysander was really believed to be a 'real' god, a question, however, which concerns all rulers honoured with i $\sigma o ́ \theta \varepsilon o r$

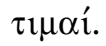

This question - to which we shall return shortly-triggered another solution, namely to smooth over ruler cult by unmasking and thus disqualifying it as a political religion. In his best-seller "Hellenistic Civilisation" W.W. Tarn accepted the reality of ruler cult adding:

This expresses a truth provided the emphasis is placed on 'political', for it had nothing to do with religious feeling (....) it was rendered possible by the general disbelief of the educated classes, for the Olympian religion was spiritually dead.

human being to Oriental influences, which he assumes to have been substantial at Samos with its famous harbour.

${ }^{69}$ Habicht 1956, 3 ff., where one can find full bibliographical data. He concludes: "der samische Kult Lysanders ist nicht nur einwandfrei bezeugt, sondern war in seinen Formen der Kult eines Gottes."

${ }^{70}$ E. Homann-Wedeking, Arch. Anz. 1965, 440. Cf. Habicht 1970, 243 f. 
Practically no word of this statement-which met with wide support in his time-can be maintained as recent scholarship and in particular Simon Price with his book "Ritual and Power" have shown. ${ }^{71}$

Greeks cannot have been so confused that they considered their rulers to be gods, can they? Can't they? "A twin is not a person, he is a bird," say the African Nuer; "I am a red parrot," says a South American Bororo; "I am the bride of Christ," says a Roman Catholic nun; ${ }^{72}$ "Men are pigs," says an uncharitable feminist. "Demetrios is a god," says an Athenian citizen. Each of them will have serious problems in grasping the meaning of each of the others' statement. In fact, we are so helpless in appreciating different types of classification, predication, metaphor or simile-including different implications of the copula 'to be'-that we prefer to deny that these expressions can have really meant what they say they mean. ${ }^{73}$ The Bororo confession, for instance, has generated a notorious and apparently endless discussion on the precise meaning of the identification with a parrot, inter alia featuring the argument that a Bororo cannot possibly be a parrot since "he does not try to mate with other parakeets." I think only a Dutch scholar can push complications to the frontiers by asking the question: "Are the Bororo Parrots or Are We?" ${ }^{4}$

It is especially in the study of religion that scholarly prejudice with respect to the limits of the imaginable tends to erect forbidding bar-

${ }^{71}$ Also in earlier times different voices could be heard. Ehrenberg 1946, 189: "we must be careful not to regard it (i.e. ruler cult) as megalomania on the part of the rulers or as servile flattery on that of the subjects," adding (190): "It has been rightly called a 'political religion.' But then it was not only politics, but also genuine religion" (my italics).

${ }^{2}$ See above all the brilliant discussion by Smith 1978, Ch. 12 'I am a parrot (red)', with the 'mating parakeets' quoted at p.267, and the prehistory of the scholarly discussion at p. 268 n.18. Cf. ibid. 296-299, and the exemplary treatment of alternating denotations of one person: the magus, the miracle worker as theios aner, and the Son of God (190-207). On the Nuer 'twin-bird' introduced by E.E. Evans-Pritchard see the ample bibliography at p. 280 n.56. A more recent, very instructive, treatment: T. Turner, "We are Parrots," "Twins are Birds": Plays of Tropes as Operational Structure, in: Fernandez 1991, 121-158. On the implications of the 'Bride of Christ' confession vel similia ("I am saved by the blood of the Lamb") see: R. Fowler, Homo Religiosus: Sociological Problems in the Study of Religion (London 1974). On the complications of interpreting Greek theos when used as a predicate see: Price 1984b and below.

${ }^{73}$ For Greek عival there is Ch.H. Kahn, The Verb 'Be' in Ancient Greek (Dordrecht 1973), who argues for a (near-)exclusively predicative function of the verb. Reconsiderations in: idem, Essays on Being (Oxford/New York 2009).

${ }^{74}$ Th.P. van Baaren, in: Liber Amicorum: Studies in Honor of C.J. Bleeker (Leiden 1969) 8-13. 
riers on our way to understanding. J.S. Helfer, ${ }^{75}$ himself a historian of religion, writes

The situation of historians of religions often fails to permit an alien world of meaning to retain its integrity because the scholar's ultimate values are threatened.

And he mentions celebrities such as Rudolph Otto, Van der Leeuw and Eliade among the scholars "whose conclusions are too clearly functions of what they assume to be limits of understanding; ultimacy situates scholarship and determines it." 76 Unfortunately, there is little reason for assuming that minor scholars suffer from minor prejudices.

We have seen some baffling attempts, launched by modern scholars, to discredit displeasing testimonies of early cultic honours for generals or kings, one of which, however, was unequivocally refuted by a more recent epigraphical finding. We have seen attempts to discredit the religious quality of ruler cult. For some sceptics the only way to come to terms with the Athenian hymn to Demetrios is by underlining its idiosyncrasy, ${ }^{77}$ and/or by accommodating it in the register of the practical joke, ${ }^{78}$ where the treatment of Menekrates by Philippos

\footnotetext{
${ }^{75}$ J.S. Helfer (ed.), On Method in the History of Religions, HङT Beiheft 8 (1968), $1-7$.

${ }^{76}$ Or, in the words of Carney 2000, 211: "Our understanding of ruler cult will always be limited. The single god of the desert and the religions that worship him stand between us and those who put up altars and gave sacrifices and festivals in the name of Antigonus. (...) Our understanding of the nature of religious experience itself is so shaped by the nature of Judaeo-Christian experience that we have had great difficulty recognizing as at all religious any belief or practice that departs very far from our Judaeo-Christian norm."

77 Of course, it does display idiosyncratic (though not entirely unique) traits. See: Parker 1996, 262, who, in the wake of Price 1984a, 38, himself calls the hymn "quite untypical" as opposed to different "non-competitive" associations between rulers and gods, which, different from the Ithyphallos, clearly reconfirm the powerful position of the normal gods: "Saviour kings could be assimilated to saviour gods precisely because saviour gods still had power."

78 "I would hesitate to accept by taking wholly seriously the paean of Hermocles (....) At the right time and place, the Greek gods, unlike most others, could take a joke," so H. Lloyd-Jones, Psychoanalysis and the Study of the Ancient World, in: P. Horden (ed.), Freud and the Humanities (London 1985) 152-181, espec. 179 n. 62; H.-J. Gehrke, Geschichte des Hellenismus (Munich 1990) 191: "teilweise spielerisch, womöglich sogar ironisch;" Weber 1995, 305: "so konnte mann manche Passagen auch eher auf eine Ironisierung hin interpretieren" with arguments; Mikalson 1998, 96: "playfulness in the song," against the background of the contemporaneous sociopolitical ambience (85): "The playful spirit of this high society is apparent." For that matter, it is a typically modern error to think that religion and humor are incompatible in ancient culture. "Modern readers tend to regard religion as by definition un-funny,"
} 
also belonged. All the same, it cannot be denied that from the early fourth century onwards, kings, tyrants and generals did receive cultic honours, including altars, sacrifices, cult hymns praising their superior power, and in later times also temples. We are still confronted with the question: what does this mean? Before we go into this let us first have one more look at the birth announcements of the new gods.

\section{The Construction of a God}

Two instruments are of seminal importance in the construction of a god: word and action, that is: language and performance. Viewed from the perspective of ritual, to which both belong, they may even be regarded as the sole viable instruments to that effect. For, indeed, "rituals often communicate things that it would be unwise or even ineffective to convey in any more direct fashion." ${ }^{\prime 9}$ One may even conceive of a mental condition in which ritual is performed, a 'ritual stance' or 'commitment' that entails acceptance of meaning. ${ }^{80}$

\section{Language}

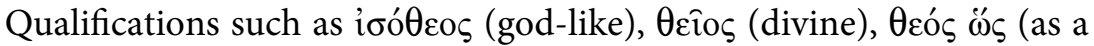
god) prevailed throughout Greek literature from Homer onwards. ${ }^{81}$ The fourth century, which witnessed a rapid increase in acclamations such

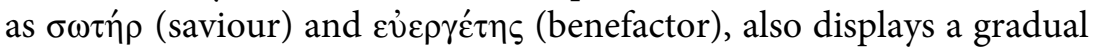
shift in allusions to divine qualities in these praises. Take for instance the cheers addressed to the Spartan king Agesilaos in the beginning of that century: $\mu \varepsilon \tau \grave{\alpha} \theta \varepsilon o \grave{\varsigma} \sigma \omega \tau \eta \hat{\rho} \alpha$ ("saviour next to" or "after the gods": Xen. Ages. 11.13). "Byzantinistic flattery" howl the sceptics, but that is demonstrably too one-sided. Obviously, grovelling may play a part in the proposal of a certain Demokles at the royal court of Syracuse to

thus J.A. North, Roman Religion (Oxford 2000) 81. Cf. P. Berger, Redeeming Laughter (Berlin-New York 1997). Hence the contemporary jokes and puns on ruler cult do nothing to disprove belief in the divinity of the rule in other social sectors.

${ }^{79}$ Kowalzig 2007, 46, in her discussion of the power of performance, to which we shall return later.

${ }^{80}$ Thus C. Humphrey \& J. Laidlaw, The Archetypal Actions of Ritual: A Theory of Ritual Illustrated by the Jain Rite of Worship (Oxford 1994), as cited by Kowalzig 2007, 51 (cf. preceding note).

${ }^{81}$ See e.g. Nock 1928, 31, with the note, worthy of consideration, that these terms are "susceptible of different meanings to different people who used it." 
dance henceforth in honour of the living Dionysios II and no longer

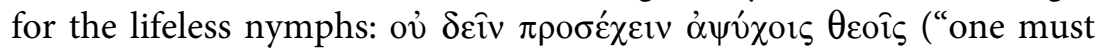
not pay attention to soulless gods:" Athen. $6.250 \mathrm{~A}$ ), a notion that returns in the hymn to Demetrios. On the other hand, flattery does not seem to have been a decisive or necessary factor in the foundation of a hero-cult in the centre of the agora for the tyrant Euphron of Sicyon after his death (Xen. Hell. 7.3.12.). ${ }^{82}$

In the same fourth century one can perceive a gradually swelling rumble in rhetorical and philosophical treatises. In a letter to king Philippos II of Macedonia Isokrates (Epist. 3.5) states that after his eventual victory over the Persians "there is nothing left for the

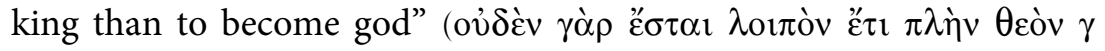
$\varepsilon v \varepsilon ́ \sigma \theta \alpha 1)$. Once more, scholars have denied this expression any trace of divinisation, this time on the ground that it is a gnomic expression

${ }^{82}$ This is the right moment to justify my silence on the possible relationship of hero-cult and ruler cult. It is one of those eternal indigestable bones of contention among specialists. According to one party, ruler cult cannot possibly be modelled after the cult of heroes on account of he restriction of the latter to the dead (Bickel, Taeger). Against this, others (v. Prott, Rohde, Kornemann, Kaerst and, most systematically, Habicht, followed by some of his reviewers mentioned in Habicht 1970, 243 n.1) hold that ruler cult can only have been moulded on hero cult on account of 1) its essentially local nature, comparable to the local city cult of the ruler, and 2) the specific motives for the cult: euergetism, city-founding. In Versnel 1974, 144-148, I have argued that if Plutarch Dion 46.1 refers to Dion's honours in Syracuse (357 BC)

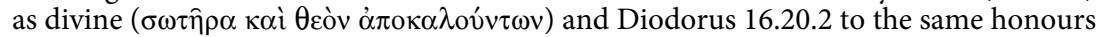

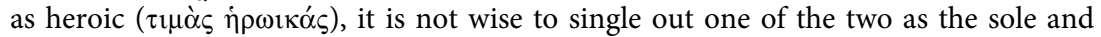
exclusive option in theoretical reflection. Both may have contributed to the creation of this new 'theology,' as Nilsson in his review of Habicht's book (Gnomon 29 [1957] 214 ff., espec. 215), already argued: "Der Kult der Heroen hat beigetragen zum Kult der Machthaber, aber dieser gründet sich nicht ausschließlich auf den Kult der Ktistai." Cf. GGR II, 135 f. E. Will, in his review of Habicht's book, aptly warned us not to start our theorizing from what existed but from what was aimed at: "la sacralisation des hommes providentiels". In the process of devising new symbolic forms for the so

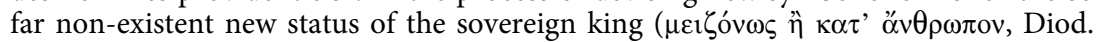
16.11.1) only two avenues were available: the heroic and the divine, and both have been fruitfully explored. Scholars seem to forget that in our evidence living rulers were practically without exception honoured with divine cults, including Olympian sacrifices (thusiai) (Lanciers 1993, 205 with n. 7) and predicates, including the predicate $\theta \varepsilon$ ćs (see the collection in Habicht 1970, 156 n. 75), not with heroic ones. For other types of superhuman humans this may be different. See especially: B. Currie, Euthymos of Locri: A Case Study on Heroization in the Classical Period, JHS 122 (2002) 24-44. Cf. on heroic honours for non-royal individuals: K. Buraselis, Political Gods and Heroes or the Hierarchisation of Political Divinity in the Hellenistic World, in A. Barzano et alii (edd.), Modelli eroici dall'antichità alla cultura europea (Rome 2003) 185-197. For a revealing example of manipulating the choice between god or hero see also below p. 494. Finally, I must point out that my subject is not origins but actual ritual, including non-city-centered forms of 'theopoetics'. 
used exactly to warn the mortal that here has been reached a limiting boundary which he should not try to transgress, the barrier between mortal and god. It expresses the same as the Pindaric maxim quoted above: "do not aspire to become Zeus... mortals should behave as mortals." ${ }^{83}$ What these sceptics fail to appreciate is that the ambiguity in the expression-which, from a purely linguistic point of view, may be a warning just as well as an exhortation-makes it perfectly liable to contextual engineering. In a period in which the first human beings are awarded divine honours, it is exactly the opposite meaningsemantically equally legitimate, but so far sleeping-that is now kissed awake. Experimenting with the gnomic, suggesting, not stipulating, that is one of the most enchanting - and rewarding - tasks of rhetoric. The same Isokrates in his praise of the city king Euagoras says that poets have exaggerated by saying about men of primeval times "that

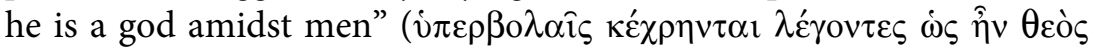

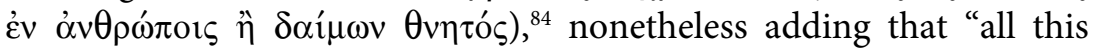
could most precisely be said about the nature of Euagoras" ("ूँ $\pi \alpha v \tau \alpha \tau \dot{\alpha}$

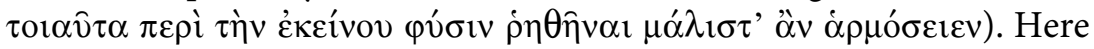
we encounter similar and indeed interrelated experiments in semantic brinkmanship. They are only two out of a host of similar ones in fourth century rhetoric serving as linguistic instruments to pave the way towards the construction of a mortal god.

So far there is nothing shocking in this. A Dutch television reporter witnessing the superhuman supremacy of the Netherlands champion during the world skating championship of 1998, exclaimed: "and yet he is born from mortal parents. His parents were human beings!" 85

${ }^{83}$ Gordon 1996, 7 speaks of "the boundary between the permissible and the impermissible" that consists in bestowing life on inanimate images as Daidalos did. Indeed, the resemblance is striking as are the ways to "gamble with the impermissible" as discussed ibidem. See below. p. 478.

${ }^{84}$ Evag. 72. The expression $\theta \varepsilon \dot{\varsigma} \varsigma \dot{\varepsilon} v \alpha \dot{\alpha} \theta \rho \omega ́ \pi$ or $\varsigma$ vel sim. was proverbial (Theogn. 339; Antiphanes, Meineke, FCG 3.121). Cf. Arist. Pol. 3. 1284a. 11, on a man of transcend-

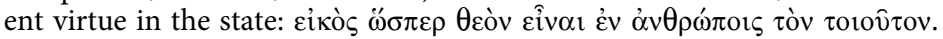

${ }^{85}$ I do not wish to accuse him of plagiarism when I note that the Hellenistic poet Rhianos (Stob. Flor. 4.34; Powell, Collectanea Alexandrina 9 f.) uses the very same expresssion when he reminds the all too fortunate, opulent, and hence haughty person (most probably referring to the Hellenistic divine ruler) "that his parents are mor-

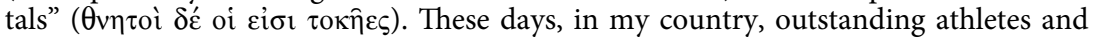
above all soccer champs are often referred to as 'godenzonen' (sons of gods). Half a century ago Dodds 1951, 242, wrote: "That Hellenistic ruler-worship was always insincere $(\ldots .$.$) no one, I think, will believe who has observed in our own day the$ steadily growing mass adulation of dictators, kings, and in default of either, athletes," 
The next Sunday Netherlands' most renowned reformed minister, also on TV, eagerly appropriated this exclamation for the instruction of his congregation. He explained that, just as the exclamation quoted might imply that the winning sportsman himself should be taken as being divine (though he is not), so Jesus' divinity was the result of a similar misinterpretation of rhetorical cheers and allusions. Indeed, in the domains of skating and that of theology things go very fast in my folkloristic little country. But the message is suggestive. Let us keep it in mind.

\section{Performance}

In Aesch. Sup. 980 ff. Danaos, who as a suppliant together with his daughters has found shelter in the city of Argos, says:

Children, offer your prayers, with sacrifice and libation, to the citizens of Argos, as to Olympian gods. For they are our saviours without doubt

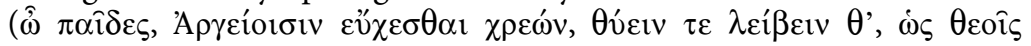

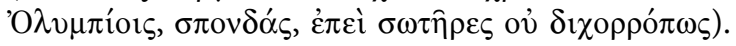

We are still on the level of poetical rhetoric, which provides more expressions of this type. ${ }^{86}$ What Danaos does is suggest, not perform. Even so, we do descry here a literary scenario of the actual performances that we observe in the fourth century.

When the tyrant Dion entered Syracuse in 357 BC, having revealed his plan to liberate the whole of Sicily, Plutarch Dion 29 describes his entry as follows:

On either side of the street where he entered the Syracusans placed sac-

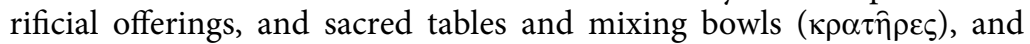

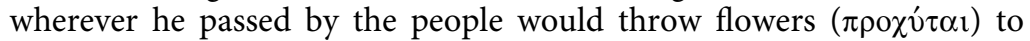

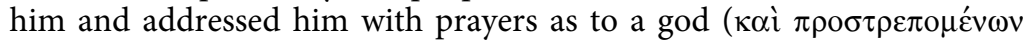

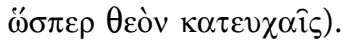

adding in n. 34: "Hitler got nearer to being a god than any conqueror of the Christian period." In all these examples the modern 'consent-model' of ritual, including verbal ritual expression, as developed in 'performance theory' is of seminal importance (see below p. 472).

${ }^{86}$ For instance $O d .8 .461 \mathrm{ff}$. Ph. Fredericksmeyer, On the Background of the Ruler Cult, in: Ancient Macedonian Studies in Honor of Ch.E. Edson (Thessaloniki 1981) 149, and Hammond 1999, 106, argue that this and other expressions especially with respect to pre-diadochic Macedonia prove that this does not imply divinisation: it is comparison, not equation. Though this is formally correct, they ignore the psychological seduction hidden in this terminology. 
Why did they do this? Diodorus 16.11 .1 gives the answer: because "everybody estimated his miraculous power as exceeding human

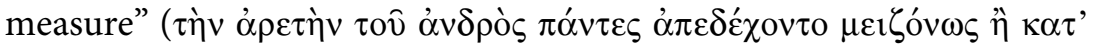

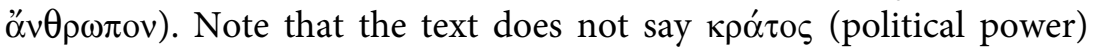
but $\dot{\alpha} \rho \varepsilon \tau \eta$, the word that we met earlier in the term aretalogy, which from the 4th century on is used to praise the superhuman feats of gods. And what was the nature of his superhuman blessings? Diodorus 16.20.6, on another occasion, tells us that the Syracusans

honoured with praises by the whole citizen body ( $\left.\pi \alpha \alpha^{\prime} \delta \eta \mu o \imath\right)$ and mag-

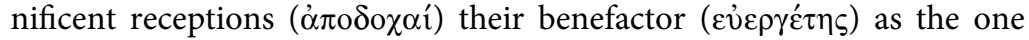

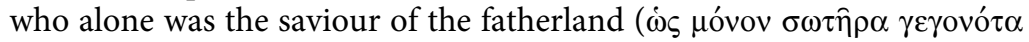
$\left.\tau \hat{\eta} \varsigma \pi \alpha \tau \rho^{\prime} \delta \delta_{\varsigma}\right)$,

while Plutarch Dion 46, in the same historical context, speaks of

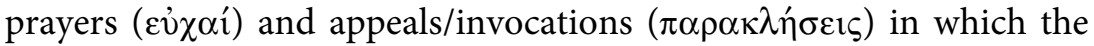

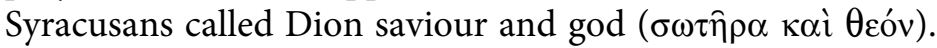

Here we have a fairly complete picture of the construction of a god: deification as an expression of praise, gratitude and the acknowledgment of achievements exceeding human measure. Indeed, here the gnomic expression "the only thing that remains is to become god" realizes its revolutionary novel implementation in a kind of theatrical play in word and action: the ruler is addressed as god in prayers and he is treated as a god with sacrifice.

This was not the first time Sicily witnessed such a thing: a century before this Empedokles, prophet and doctor, claimed that he was a god on earth, ${ }^{87}$

An immortal god, mortal no more, I go about honoured by all, as is

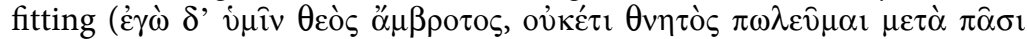

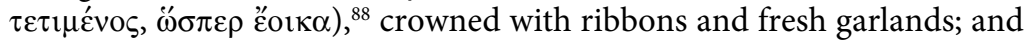
by all whom I come upon as I enter their prosperous towns, by men and women, I am revered. They follow me in their thousands, asking where lies the road to profit, some desiring prophesies, while others ask to hear the word of healing for every kind of illness, long transfixed by harsh pains.

${ }^{87}$ Fr. 112, KRS Fr. 399, whose translation I have adopted.

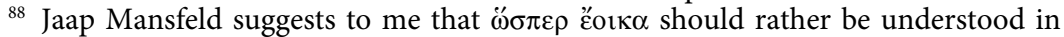
the sense of "according to the way I look like" (referring to what follows), and that this suits the theatrical interpretation that I shall propose below. 
And in Fr. $146=$ KRS 409, speaking of daimones who gradually will ascend through ever higher realms of creation (as he himself is doing) he writes:

But at the end they come among men on earth as prophets, bards, doctors and princes (îๆ and thence they arise as gods highest in honour, sharing with the other immortals their hearth and their table, without part in human sorrows or weariness.

Other sources confirm that Empedokles was received in that quality with great pomp and reverence in Sicilian cities. Note how doctorswe are back at Menekrates-and kings or tyrants-Dionysios, Dion, Demetrios-are closely united in their deifications. This confirms that, though political and military salvation may be the most conspicuous aretai, they are not the only qualities that may open the gate to heaven. Note, too, how sharing the table and the dishes of the gods is one of the specific markers of apotheosis, a theme to which we shall have to return.

\section{Did (the) Greeks believe in the Divinity of their Rulers?}

When we now turn to the question announced in the title of this chapter, we should realize that this brings us dangerously close to a vexing and in my view sorely misguided recent campaign against the legitimacy of using the terms 'belief/believe' in the study of Greek religion. In Appendix IV I hope to demonstrate the absurdity of this modern doctrine. However, we need not wait for the result of that enquiry before tackling the question of the present section: belief in (the existence of) god or gods is not the same as believing that a human being (specifically a ruler) is (a) god. Many different avenues (and back alleys) have been taken to allay the threat hidden in this question. Earlier we have encountered a few arguments against the religious quality of ruler cult. Another, very popular, reaction is the appeal to scepticism, criticism or derision of ruler cult, to be found throughout antiquity ${ }^{89}$ including the earliest period of the deification of the ruler.

\footnotetext{
${ }^{89}$ K. Scott, Humor at the Expense of the Imperial Cult, CPh 27 (1932) 317-328; J. Tondriau, L'avis de Lucien sur la divinisation des humains, Lettres d'Humanité 7 (1948) 127-138, and in MH 5 (1948) 124-132; Habicht 1970, 213-221: 'Zeitgenossische Polemik gegen den Kult'; G. Bowersock, Greek Intellectuals and the Imperial
} 
We have already met king Philippos' derisive reaction to Menekrates' pretensions, and the Athenians' reactions to that king's own deification at Kunosarges (above n.24). Demochares' list of the divine honours bestowed on Demetrios, ${ }^{90}$ including a summary of the hymn, is from beginning to end interspersed with terms such as ко $\lambda \alpha \kappa \varepsilon i ́ \alpha$ (flattery). Plutarch, who in his Life of Demetrius 10-15 (probably influenced by Demochares) also gives a collection of these privileges, introduces

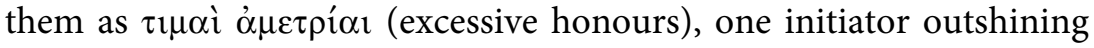

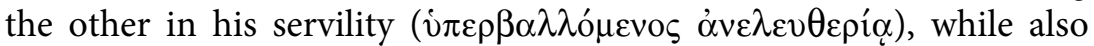
referring to contemporary reactions. ${ }^{91}$ Various types of mishap were interpreted as tokens of divine displeasure with their new colleagues Demetrios and Antigonos: the sacred peplos (robe) displaying pictures of the gods, in which the images of Demetrios and Antigonos were to be woven, was ripped in two by a hurricane; all round the altar of the 'Saviours' hemlock sprouted; the procession of the Dionysia had to be cancelled on account of an unseasonable severe frost which destroyed both grape and corn.

I relate this so extensively because Plutarch Demetr. 12.4 (cf. 26.3) also quotes a fragment by the comedy writer Philippides, ${ }^{92}$ in which he attacks Stratokles, the initiator of many of these divine honors:

Through him (i.e. Stratokles) it was that hoar-frost blasted all the vines, Through his impiety ( $\alpha \sigma \varepsilon \beta o v v \tau \tau \alpha)$ the robe was rent in twain,

Because he gave the gods' own honours unto men.

Such work destroys a people, not its comedy.

Cult in the Second Century AD, in: W. den Boer (ed.), Le culte des souverains dans l'empire romain (Entretiens Hardt 19, 1973) 179-206. Both sides in: Th. Paulsen, Verherrlichung und Verspottung. Die Gestalt des 'Gottmenschen' bei Philostrat und Lukian, in: G. Binder, B. Effe \& R. Glei (edd.), Gottmenschen. Konzepte existentieller Grenzüberschreitung im Altertum (Trier 2003) 97-120.

${ }^{90}$ FGrH 75 no. 2 (Athen. 6.62.253B-D). Cf. Habicht 1970, 214 ff., also referring to the important 'demythification' of Plutarch's targets by L. Robert, Hellenica 2 (1946) $28 \mathrm{ff}$.

${ }_{91}$ Weber 1995, 301 notes that Demetrios was easily the most controversial person in this regard, due to the conjunction of his extravagant behaviour and the place where it was staged: Athens. At pp. 301-305 he gives a survey of reactions in contemporaneous literature.

${ }_{92}$ CAF III p. $308=$ PCG VII p. 347 There is a good discussion of this and other fragments of Philippides relevant to Demetrios by: G.B. Phillip, Philippides, ein politischer Komiker in hellenistischer Zeit, Gymnasium 80 (1973) 493-509, espec. 505 ff. He convincingly opts for a date around $301 \mathrm{BC}$. 


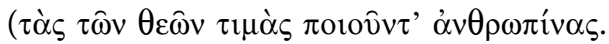

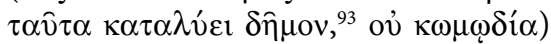

Obviously, these reactions-including one by king Antigonos deriding his own divinity by remarking "the man who empties my chamber pot has not noticed it" (Plut. Is. et Os. 24, Mor. 360CD)-breathe an intellectual atmosphere. As such, however, they are scarce and offer no more proof of a general rejection or disbelief, than do philosophical (Xenophanes, Epicurus), literary (Euripides), comical (Aristophanes) passages with gods as objects of criticism and laughing-stocks, as we have them also in 'Götterburlesken' in all types of literature from Homer onward.

Consequently, scholars do not stop mulling over the grade of mental authenticity in the reception of ruler cult, since, they argue, our evidence simply does not leave us a choice. Why should Greek authors-comedy writers and others-try to deride or otherwise undermine the various contemporary deificatory strategies by exposing the overtly mortal aspects of the new gods, if they did not detect or assume an element of belief in those who endorsed them? And, for that matter, we have seen that it was not always the ruler or his courtiers who initiated the process of deification (as modern scholars are increasingly ready to admit).

If, then, there still is a justification for the question 'did the, or most, or some Greeks believe in the divinity of their ruler' or more directly 'did they believe that their ruler was (a) god', we must now first briefly propound three preliminary considerations.

First, there is the eminently polythetic nature of the notion theos. Amazingly, not one of all those we have seen squabbling about the problems around the equation of Greek nomizein and English 'believe' has brought to notice that exactly the same is true for the question: "does Greek theos equal English 'god'?" In the background there may have been the fear that this would have complicated matters to an unmanageable degree. Nor, for that matter, is it possible to start a discussion of this issue here, on which there is amazingly little serious

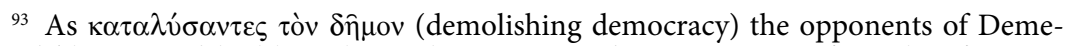
trios' 'democracy' had been banned in $307 \mathrm{BC}$. The expression is formulaic for antidemocratic threat: Versnel 1990, 56 f. n. 52. 
literature to begin with. ${ }^{94}$ For the moment let it suffice to refer toperhaps the best-very brief discussion by Simon Price 1984, 79 ff., in particular his emphasis on the predicative use of the word as in the sentence "this is (a) theos." Things, experiences, events, and human beings can all be predicated as being theos. Here indeed a wide range of possible interpretations reveals itself. Calling someone theos in fourth century rhetoric of praise, as we saw, need not have exceeded the level of the simile. But we have also observed that with the performative elaborations of this language of praise a potential crossing of borderlines came into view. Price's quotation of Carneades' wellknown arguments about gods in Cicero ND 3.43 is of great consequence for the next step in our own enquiry:

If gods exist, are the nymphs also goddesses? If the nymphs, are the Pans and the Satyrs also gods? But they are not gods; therefore the nymphs also are not gods. Yet they possess temples vowed and dedicated to them by the nations. Therefore the other gods who have had temples dedicated to them are not gods either.

Price comments: "Of course, Carneades with this little by little approach had a different agenda, nor is it an essential issue whether his argument is decisive." Let this suffice as a good illustration that there were no uncontroversial criteria for the predication of theos. The boundaries of the concept were not unequivocally defined. And we have come to the centre of things with his conclusion: "there are unproblematic uses of the concept (e.g. Zeus) but at the edges problems arose. Were the nymphs, or satyrs, or emperors theoi? Was its predication of the emperor aberrant in comparison to its predication of the traditional gods?" Indeed, if the shared attribution of temples (and altars, sacrifices, and hymns) to nymphs, Pan, Satyrs and gods can be used as proof that none of them are gods, then, contrarily, they may also serve to confirm that all of them are gods, an interpretation that also may extend to human beings addressed and treated as gods. And it is this potential for ambivalence-the same as what we earlier discovered

\footnotetext{
94 Price 1984, 79: "Theos, though a basic term of Greek religion, has never been given a detailed semantic study", mentioning two exceptions: W. Pötscher, Theos. Studien zur älteren griechischen Gottesvorstellung (Diss. Wien 1953); W. Burkert, Griech. Rel. 406-8 (= Burkert 1985, 271 f.). The situation has not changed dramatically since. With the exception of Burkert's contribution on the origin of the concept theos, A.B. Lloyd (ed.), What is a God? Studies in the Nature of Greek Divinity (London 1997) does not help much.
} 
in the expression "there is nothing left for the king than to become god"- that we must examine a bit further.

Secondly, we should be aware that belief in the gods and belief in the divinity of the ruler, being both treated to the same cultic rituals, are more or less in the same boat, at least in one respect. ${ }^{95}$ In attributing divine predicates and cultic privileges to a mortal ruler, and thus 'making him theos', people were focussing on a selection of predicates, with no necessary urge to complete the whole gamut of divine qualities usually attributed to gods. Qualities such as (im)mortality, changing positions in (in)visibility, and various forms of miraculous behaviour simply remained out of scope, just as we have observed them doing in the communication with 'real' gods when a context required it.

In this respect we should heed the risk that my compatriot Ruurd Nauta, writing on panegyrical poetry, coined 'the danger of totalizing comparisons ${ }^{3} .^{96} \mathrm{He}$ introduced the term in order to expose the type of overinterpretation that finds hidden meanings (and irony) at random in poetic texts. The central question concerns the uncertainty about how far the tertium comparationis, the common ground of the comparison, extends. The danger lies in the technique of arbitrarily extending the instances of the tertium comparationis beyond the one that was obviously and unequivocally intended by the author. This method, for anyone who is on the lookout for it, will always produce irony. Nauta concludes $(2002,426)$ :

A poet must have been able to trust his audience that it would not add extraneous elements to the tertium comparationis. To put this in more general terms: panegyric is only possible on the basis of a contract between the poet and his audience which defines the context (....). The words themselves cannot put an end to the attribution of meaning: only the situation in which the words are uttered can.

In the last phrase, as so often earlier in the present book, the fundamental import of context once more comes to the fore. A sample of it can already be found in our discussion of the various divine associations in the Demetrios hymn. As a whole the passage just quoted is a perfect expression of what I will argue concerning the special nature

\footnotetext{
${ }^{95}$ For a subtle treatment of relevant inconsistencies in Kallimachos' works see Bulloch o.c. (above n. 36).

${ }^{96}$ In his dissertation Poetry for Patrons: Literary Communication in the Age of Domitian (Leiden 1995) and in a revised form in his book under the same title (Leiden 2002).
} 
of the divinity of the ruler. ${ }^{97}$ The viability of a selective exclusion of unwelcome qualities is due to man's ability to mean what he says and does during ritual (e.g. around the festive entrance of a king) without feeling the need to reconcile these statements with the rest of his experience. And herewith we arrive at our third consideration.

Thirdly, then, and finally, we should call to mind the words of King 2003, 277 about the Romans (which just as well holds for the Greeks) that "they possessed specific alternative mechanisms for the organization of beliefs that allowed clusters of variant beliefs to exist within Roman [Greek] society without conflict." It may very well be that if we find hints of belief in the divinity of the ruler, the 'mechanisms' of it may vary from the ones involved in the belief in the existence of gods and yet no less deserve the denominator 'belief. Or in the words of William James 1890, 290:

The whole distinction of real and unreal, the whole psychology of belief, disbelief, and doubt, is thus grounded on mental facts-first, that we are liable to think differently of the same; and second, that when we have done so, we can choose which way of thinking to adhere to and which to disregard.

\section{Ritual Play: Sincere Hypocrisy}

What kind of belief are we talking about: belief or make-believe? It is time to devote a few words to the concept of the ludic. According to the Dutch poet and novelist Frans Kellendonk, religious belief should be basically defined as a form of 'oprecht veinzen', i.e. 'honest dissembling/simulating' or 'sincere pretence'. Hence he ranges it among the devices of irony: people feign to know what they are talking about though at the same time being aware-consciously or unconsciouslythat this is not a reality that can be proven or touched: in religion people live by images, images constructed by their own imagination. ${ }^{98}$

97 Cf. S. Goldhill, The Poet's Voice. Essays on Poetics and Greek Literature (Cambridge 1991) 271-283, espec. 279, on "the need for selective, controlled reading of an encomium-a reader's necessary participation in the social performance of encomium."

98 The relevant sections of his work plus some reactions and comments by critics are collected in: Ch. de Cloet e.a. (edd.), Oprecht veinzen: over Frans Kellendonk ('s Gravenhage 1998). Several critics disagree with his position. I am not arguing that every type of 'belief' satisfies this specific definition, but I do feel that it perfectly covers the theatrical type of belief under discussion here. For that matter, Kellendonk may have invented the terminology but not the concept: it already claims a central place in 
The anthropologist Nigel Barley was once watching a religious ceremony in Central Africa. He had an informant, who described to him what was going on. "The man in the feather headdress is now taking the sacred objects out of their hut." "But I don't see a man in a feather headdress," replied the anthropologist. "No, he is not wearing it," answered his informant. I owe this little anecdote to Richard Gordon, who cited it in a paper given at Leiden some years ago, with the inference that

religion, in other words, is in the mind. It consists not so much in religious acts as in schemes of perceptions and thoughts whose meaningfulness is repeatedly reinforced by the performance of symbolic acts.

And after adding a well-known instance from Roman religious ritual, ${ }^{99}$ he concluded:

So many pious fictions, so much honest pretence. And hardly anyone, outside the ranks of the philosophers, cared about the truth.

Belief as sincere dissembling, religion as honest pretence-in the specific context where our topic brought us, an alternative, even more apposite, expression prompts itself, namely 'honest hypocrisy'. The Greek word iкокрıтń means both actor-one who plays a part on the stage-and dissembler, pretender, hypocrite. And it is in the world of theatrical performance that we have obviously landed. Ritual, at least the type of ritual that we are concerned with, is a form of make believe, of theatre, of play. ${ }^{100}$ This means that while performing or attending ritual-and it should be noted that in ritual, however 'spectacular' it may be, the participants are actors at least as much as they are spectators-one has two options: either to fully (and sincerely)

Kierkegaard's notion of irony, the notion for which Kellendonk's 'sincere pretence' is an alternative. On the limits of equating 'make-believe' and 'pretence' in writing and reading fiction see: G. Currie, The Nature of Fiction (Cambridge 1990) $50 \mathrm{f}$.

99 POxy 3781 reports that when Hadrian succeeded to the throne in $117 \mathrm{AD}$, on the death of Trajan, a public performance was held, apparently in Egypt, in which an actor, playing the part of the god Apollo, came forward to declare that he had just escorted Trajan to heaven in a chariot drawn by white horses, and had now come to announce the new emperor's accession to the people. Others tell us that an eagle was released from the top of an emperor's funeral-pyre as the flames consumed the body below: "the bird is supposed by the Romans to bear the emperor's soul from earth to heaven" (Herodian 4.2.11).

${ }_{100}$ Performance is the sine qua non of ritual, according to R. Rappaport, Ecology, Meaning, and Religion (Berkeley 1979) 176 f., and see Kowalzig 2007, $46 \mathrm{n} .107$ for literature on the performative nature of ritual, which is in the centre of recent interest. 
pretend or to break the rules of the game. ${ }^{101}$ The first option entails the condition that the spectator is willing to accept emotional involvement in the spectacle. He should 'surrender' to the 'reality' of fiction. This means that he must abandon the attitude of the 'onlooker' and adopt the one of the 'theatregoer.' ${ }^{102}$

Recognition of the theatrical and performative nature of ritual provides us with a variety of avenues towards assessing the acceptance of ruler cult. One of them relates to the inherent 'power' of ritual. It has been long observed that ritual coerces its participants into a position of acceptance. This aspect of ritual has been elaborated on in modern 'performance theory' and particularly in the ritual adaptation as proposed by Bloch 1989, who denies ritual any propositional force (see below p. 490 f.). The inference he draws from this is the following:

Because participants do not challenge the routine formulae or conventions, formalization is thus very effective in promoting a loose compliance with the social roles depicted in the ritual: acceptance of the mode of presentation coincides with acquiescence in the content.

As regards "the routine formulae and conventions" we must realize that all ritual building stones in the creation of ruler cult are adopted from existing forms of divine cult; hence they are, in this sense, traditional. The revolutionary novelty was not their forms but their transference onto the cult of the ruler. The latter aspect concurs with the element of dynamics, mentioned as a desideratum by Kowalzig: ${ }^{103}$

While the Blochian model is itself rather static, it can produce a fruitful dynamic among participants in ritual who constantly move between resistance and consent. Compliance and defiance, so it is argued more recently, determine both ritual's efficacy and its limitations.

The second access to an understanding of the public reception of ruler cult, while also clarifying the prevalence of 'compliance' over 'defiance' beyond the issues of 'coercion' and 'consent-model'-is to continue

101 Cf. Pruyser 1968, 190: "Playing creates a new order which is within its space and time absolute: deviations from the rules break the spell and ruin the game. They terminate all play..."

${ }_{102}$ These terms and concepts are introduced by E. Goffman, An Essay on the Organization of Experience (Cambridge 1974). E. Hall, Towards a Theory of Performance Reception, in: E. Hall \& St. Harrop (edd.), Theorizing Performance: Greek Drama, Cultural History, and Critical Practice (London 2010) presents important insights in this and related aspects of theatrical performance.

${ }_{103}$ Kowalzig 2007, in her section on the power of ritual (43-55), whose discussion I have followed in this passage. 
our analysis of the mechanisms at work in man's commitment to theatrical ritual or different types of encounters with the fictional. That is what we now set out to do.

Ancient authors occasionally show an awareness of the fictionality of ritual. Sciendum sacris simulata pro veris accipi ("You must keep in mind that what is simulated in sacred rituals is accepted as true") wrote Servius. ${ }^{104}$ It will be hard to find a more poignant expression, ancient or modern, of this 'hypocritical belief' and its concomitant ritual behaviour than the curiously 'modern' admonition ascribed to Philemon, ${ }^{105}$ a writer of New Comedy and a contemporary of Demetrios Poliorketes:

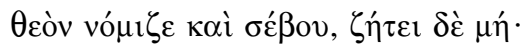

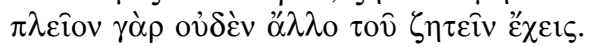

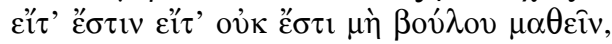

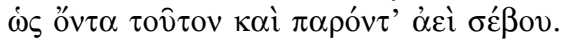

Believe in god and worship him, but seek him not:

you'll have no other profit than the search.

Don't try to find out if he is or not,

but worship him as if he is.... and present!

This little poem is focussed on the question of religious belief, not concerning divine rulers but with regard to gods. However, it beautifully shows that the inherent problems and their solutions are nearly identical for the two categories: regardless of whether the doubts regard the existence of gods or the divinity of rulers, stop wasting your time with worrying and thinking. Do as if by just performing the proper rituals.

The concept of 'the ludic' is of central interest in current anthropological and religious studies. ${ }^{106}$ Following recent theory, ${ }^{107} \mathrm{I}$ adopt

104 ad Verg. Aen. 2.116. I owe this reference to Lily Knibbeler.

105 Thus Kock, CAF 2, no.118 a b (Stob. Ecl. 2.1.5 a b). Kassel-Austin, PCG VII p. 317 do not accept Philemon as the author. For some closely related assertions see below, the Epilogue of this book n.7.

${ }_{106}$ Of course, in the first place the works of Victor Turner should be mentioned. First signs of his interest in play, the ludic, already in The Ritual Process. Structure and Anti-structure (Harmondsworth 1974); ever more increasing and-particularly important for the issue under discussion-more and more focussed on theatrical aspects in: Dramas, Fields and Metaphors. Symbolic Action in Human Society (Ithaca and London 1974); From Ritual to Theatre. The Human Seriousness of Play (New York 1982); The Anthropology of Performance (New York 1988). But also in other disciplines the interest in play grew, as for instance in the psychological approach of D.W. Winnicott, Playing and Reality (London 1971).

${ }^{107}$ I am indebted to André Droogers for drawing my attention to this new centre of interest with his contribution to a conference on Turner: 'Turner, spel, en de 
the definition of the ludic as the capacity to deal simultaneously and subjunctively with two or more ways of classifying reality. With regard to the term 'subjunctive' I here follow Victor Turner who distinguishes between the 'indicative mood', the domain of the 'as is', and 'the subjunctive mood... used to express supposition, desire, hypothesis, or possibility," the domain of the 'as if.' ${ }^{108}$

Simultaneity is the other defining term. This concerns the 'double awareness' of the player. ${ }^{109}$ After Huizinga with his Homo Ludens had contributed a revolutionary new insight into the nature of the ludic and especially into the seriousness of play, ${ }^{110}$ recent theory has put ever more emphasis on the simultaneity of seriousness and play. This implies that the ludic is not an extra, but part and parcel of human reality. The compartmentalization and pluralism that are characteristic of modern society-in other words: our modern separative cosmologyhas made us blind to that characteristic. In Victor Turner's terms: the 'indicative mood' has overcome the 'subjunctive mood'. ${ }^{111}$ The ludic has been exiled to its own sphere. Modern society has thereby lost sight of play's real nature and it must be said that postmodernism has partly recovered this perspective. As Droogers, to whom I am much indebted for these insights, writes in conclusion (p. 53):

The ludic capacity implies a double view of reality, it combines perspectives. One application of the ludic capacity is therefore the art of handling contradictions, dichotomies and paradoxes. In scientific methodological terms, the ludic represents an eclectic, poly-paradigmatic way of looking at reality.

I could have used this concept of simultaneity as a motto for all the earlier chapters, where I referred to notions of double awareness with terms such as multiperspectiveness, luxurious multiplicity, asyndetic parataxis, complementarity, double track procedure. Nowhere, however, is the concept more productive than in our present issue, which

verklaring van religie', published in Anthropologische Verkenningen 13 (1994) 31-45, revised and translated as 'Methodological Ludism: Beyond Religionism and Reductionism', in: A. van Harskamp (ed.), Conflicts in Social Science (London-New York 1996) 44-67. In my text I borrow both his definition, its foundations and parts of his phrasing.

${ }_{108}$ Turner 1988, 25; 169.

109 As suggested by Pruyser 1968, 190.

110 Cf. Pruyser 1968, 189: "The opposition between play and seriousness is only partially true, for playing has a seriousness all its own."

111 Turner 1988, 101. 
simply is about the 'honest hypocrisy' as embodied in serious roleplaying-both on the part of the actor and on that of the co-acting spectators. Perhaps the reader recalls an earlier admonition to keep in mind the little Greek word $\dot{\omega}$, 'as if', being one of the most productive tools in the creation of religious imagery. Well here it is back. ${ }^{112}$

Playing (the) god (as Dion, Dionysios and Demetrios did, followed by a long series of rulers, tyrants, kings and emperors) and playing $a$ god (as Menekrates, Alexarchos and Klearchos did), also, albeit less frequently, imitated in later times, despite all their differences share at least one thing: the element of performance, role-playing, including the need for dressing up. Some of these early divine protagonistai are recorded as having worn cothurni and other theatrical attire. In other words, also in the literal sense of the word they played the god. Demetrios Poliorketes was notorious for his extravagant array of cloaks and head gear, his purple robes and gold embroidered shoes, ${ }^{113}$ and otherwise theatrical demeanour. ${ }^{114}$ No doubt one of the incentives for this behaviour was the all-pervasive impact of theatrical performances on the mentality of contemporary people in the Hellenistic period. ${ }^{115}$ A century before this, Thucydides 3.38.4 already noted that in Athens public life increasingly resembled a spectacle, ${ }^{116}$ and it has long been

112 For instances of rulers honoured $\dot{\omega} \varsigma$ or $\omega \sigma \sigma \pi \varepsilon \rho$ followed by a choice of predicates like soter, euergetes, ktistes, theos etc. see: Habicht 1970, 169 n.14; 172 and passim. Most explicit we find it in the little poem by Philemon just quoted (p. 473).

${ }^{113}$ Espec. Plut. Demetr. 41.6 ff.; 42, 44.8.

114 Plut. Demetr. 18.5 explicitly describes his attitude as that of a tragic actor, in pace, gestures, voicing, while adding at 41.6 the comparison: $\dot{\omega} \zeta \dot{\alpha} \lambda \eta \theta \omega \hat{\omega} \tau \rho \alpha \gamma \omega \delta \dot{\alpha} \alpha \mu \varepsilon \gamma \alpha \dot{\alpha} \lambda \eta$. "Auch hier nähert sich sein Gehabe immer mehr dem eines sich selbst inszenierenden tragischen Schauspielers" (Weber 1995, 300). See the full discussion by A. Mastrocinque, Demetrios Tragodoumenos (Propaganda e letteratura al tempo di Demetrio Poliorcete), Athenaeum 67 (1979) 260-276. Cf. Thonemann 2005, 66 on Demetrios as "tragic hero and an actor in a drama," and $74 \mathrm{ff}$. on his role in the Dionysia.

115 See the fundamental article by Chaniotis 1997a, from which I borrowed various references and quotations. In the Hellenistic period we also descry a remarkable increase in emphasis on the scenic staging of public ritual, especially the processions, a fixed element in ruler worship: A. Chaniotis, Sich selbst feiern? Die städtischen Feste des Hellenismus im Spannungsfeld zwischen Religion und Politik, in: P. Zanker \& M. Wörrle (edd.), Stadtbild und Bürgerbild im Hellenismus (München 1995) 147-172; idem, Theatre Rituals, in: P. Wilson (ed.), The Greek Theatre and Festivals: Documentary Studies (Oxford 2007) 48-66, on religious and secular rituals performed in the theatre. Cf. J. Köhler, Pompai. Untersuchungen zur Hellenistischen Kultur (Frankfurt 1996); Chaniotis 2003b, passim.

${ }^{116}$ On theatricality in 5th century Athenian politics and society see the literature in Chaniotis 1997a, 220 n. 10. In her paper 'Aristophanes: The Performance of Utopia in the Ecclesiazousae' in: Goldhill \& Osborne 1999, 167-179, F. Zeitlin treats this 
observed that a 'theatrical mentality' characterized many aspects of Hellenistic life, ${ }^{117}$ not least the royal court. ${ }^{118}$ Plutarch Demetr. 18 notes that Demetrios changed his behaviour as soon as he had received the diadem and makes the explicit comparison with tragic actors "who adapt to their costumes their gait, voice, posture at table, and manner of addressing others." 119

Once more: did (the) Greeks believe that (some of) their rulers were divine? One problem in such a question, of course, lies in the word 'the.' The man who emptied the chamber pot of king Antigonos' (above p. 464) probably did not, at least not during these very 'indicative' activities. Nor did the poet Philippides or other critics belonging to the intelligentsia. However, not for the first time we are confronted with another question, namely that of whose viewpoint we are interested in: is it only that of the intellectual elite? What, then, about the masses? Are they less interesting then the few whose literary products have come down to us?

The second, even more burning problem as we have seen, lies in the notion 'believe'. After our exploration of the ludic aspects of 'believe' we may now rephrase our earlier findings as follows. If we let ourselves be harangued by the Heidelberger Catechismus and modern logicthat ill-fated alliance that has done so much to destroy our ability to understand religious expression in its historical and cultural perspectives-then (the) Greeks did not believe in the divinity of their human gods, if only for the reason that they did not try to mate with real

Aristophanic comedy as an exemplary proof of the "theatricalization of civic experience in a variety of institutional contexts and discursive practices." Various contributions to Dobrov 1997 analyse the interplay between comedy and the socio-political reality of fourth century Athens.

${ }_{117}$ J.J. Pollitt, Art in the Hellenistic Age (Cambridge 1986) 4: "In the Hellenistic period one gets the impression that life was sometimes seen as a reflection of the theatre." Chaniotis 1997a, espec. 249, who quotes this, argues that it was not only 'seen' as theatrical, and that it was not "an invention or a stylistic feature of contemporary literature," but that inversely political life and the public appearances of kings in particular took an increasingly theatrical expression.

${ }_{118}$ On the royal court as the stage of theatrical performance see: $\mathrm{H}$. von Hesberg, 'The King on Stage,' in: B. Bergmann \& C. Kondoleon (edd.), The Art of Ancient Spectacle (Washington 1999) 65-75; Strootman 2007, $260 \mathrm{f}$.

119 On Demetrios' theatrical behaviour see: Chaniotis 1997a, 244 f., referring to A. Wallace-Hadrill, Civilis Princeps: Between Citizen and King, JRS 72 (1982) 32-48, espec. 33 f.; J.J. Pollitt, o.c. (above n. 117) 6 f.; H. von Hesberg, Temporäre Bilder oder die Grenze der Kunst. Zur Legitimation frühhellenistischer Königsherrschaft im Fest, JdI 104 (1989) 61-82, espec. 77. 
gods. ${ }^{120}$ However, if we take the word "believe" in the sense of "honest hypocrisy' as is required from an audience during a theatrical play, ${ }^{121}$ the answer will probably be different and certainly less apodictic. The Greek spectators of-and hypokritai in-this 'divine comedy' may well have reacted like any theatre audience by temporarily 'believing' what happens on the stage (= honestly pretending that what they saw and heard is true) and resisting the temptation to look behind the theatrical masks or behind the scenes. The well-known portrayal of the audience's attitude during a stage-play as 'willing suspension of disbelief' is an ideal summary of my argument. Or to quote an illuminating passage from Pruyser 1968, 190, who introduced notions such as 'double awareness', 'duplicity of experience', and 'playful "as if" character' in the study of ritual:

The player has a double awareness: he knows that there is a world "outside" the play circle with whose mores he must be in tune in order to survive, and he knows that there is another world inside the circle to which he must be fair as long as the play lasts. While being seriously and perhaps even strenuously involved in playing the game, giving it all he has in skill, speed, strength, or cunning, he also knows that "it is only play" and he can "step out of it." While entering into and getting out of the play are voluntary, being in it is a great compulsion. This double awareness of the player can become so acute that he may find himself playing the game in all seriousness while also knowing that it is not real.

Both ritual and theatrical play carry strong fictional aspects. The consequences in terms of credibility are comparable. T.S. Coleridge, who coined the expression 'willing suspension of disbelief' in his Biographia literaria ch. 14, applied it to 'poetic faith', referring to the willingness of a reader or viewer to accept the premises of a work of fiction, even if they are fantastic or impossible. We are back in the field of fiction, literary fiction this time. Besides the demand of involvement and 'surrender' required from any type of audience, narrative fictions require from the reader ${ }^{122}$ that he treats the story as true. This implies

${ }^{120}$ If this disrespectful pun on mating parakeets (above p. 458) will be forgiven. Note, however, that Demetrios and other kings did not shrink from courting goddesses (above n. 58).

${ }^{121}$ Note that ancient authors regarded illusion and deception as the essential effect of theatrical acting: Chaniotis 1997a, n. 18, gives the evidence.

${ }^{122}$ That is from those readers whom P. Rabinowitz, Before Reading: Narrative Conventions and the Politics of Interpretation (Ithaca 1987) ranges among the category of 
an appeal to his generosity: the reader is expected not to 'see' obvious inconsistencies. Many are the strategies, launched by both author and audience, in order not to notice implausibilities, intrinsic contradictions and mere impossibilities. Authors may put elements of their stories in the limelight in order to ensure that inconspicuous irregu-

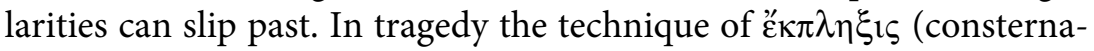
tion) is effective: "The more involved the audience, the less scrupulous its members will be," thus Ruth Scodel, to whose discussion of these conventions and strategies I refer the reader, and elsewhere "A generous audience may choose to treat an error of fact as a property of the fictional world." ${ }^{123}$ More generally, "the audience is willing to accept a good deal and to supply a good deal." ${ }^{24}$ All this is equally true for the divine ruler in his theatrical role and it radically changes the frame of interpretation of the notion 'belief in the context of ruler cult.

Finally, a related analogy presents itself in another world of imagery and invites us to once more rephrase in different terms our initial findings concerning 'belief'. Gordon 1979 discusses the representation of both god and man as living beings in 'Daedalic' plastic art in such a way that the result imitates life to the extent of becoming deceptively real, without however ever being really real. ${ }^{125}$ In this context he speaks of strategies of 'illusion.' Our present issue is the representation of a

the 'narrative audience' as opposed to the readers belonging to the 'authorial audience', who in Rabinowitz's construction posit themselves on the level of the author and, though seeking to appreciate the literary work, do not (fully) comply with the requirement of belief.

${ }^{123}$ R. Scodel, Credible Impossibilities. Conventions and Strategies of Verisimilitude in Homer and Greek Tragedy (Stuttgart-Leipzig 1999), 16 and 18 respectively. At p. $122 \mathrm{f}$., she refers to this strategy as 'Homeric rule of inattention'. The use of हैк $\pi \lambda \eta \xi_{1 \varsigma}$ to conceal inconsistencies comes close to Longinus' view of the essence of rhetoric, namely to make us "seize upon the stronger element, so that we are attracted away from the demonstration of fact to the startling image, and the argument lies below the surface of the accompanying brilliance," as translated and commented upon by Kirwan 1990, $128 \mathrm{f}$.

${ }_{124}$ P.E. Easterling, Presentation of Character in Aeschylus, G\&R 20 (1973) 5, speaking of tragic drama.

${ }_{125}$ In the Egyptian royal titulature the king may be called 'living image of Zeus'

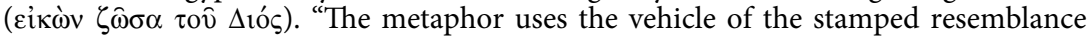
on a coin or the likeness of a statue; it presupposes the use of images to portray the deity, but by the addition of 'living' applies this to the person of the king himself. His life becomes the image of the deity" (S.R. Llewelyn, The king as 'Living Image' of Zeus, NDIEC 9 [2002] 36 ff.). S. Iles Johnston, Animating Statues: A Case Study in Ritual, Arethusa 41 (2008) 445-478, points out that the ritual act of bestowing life upon a statue in Graeco-Roman religion is not attested before late Antiquity, especially in theurgy. 
man as a god in language and performance, in panegyrics and cult, and in plastic art, in such a way that the mortal imitates god to the extent of becoming deceptively divine, without however ever becoming 'every inch' a god.

Asked if the statue is a living being the spectator might answer: in some respects yes, in others not: we do not observe the statue walking, eating, speaking, breathing, except for instance in our dreams. But as long as we are admiring this Daedalic work of art, we do not wish to renounce our illusion. Asked if Demetrios is a god, the spectator's answer might be: in some respects he is, in others not. 'Not every inch', for instance, since gods are larger than life-size. Demetrios cannot make himself invisible, nor does he fancy knise nor do we expect him to live eternally. But the spectators do not wish to give up their illusion during the momentary experience of his superhuman presence. We are speaking here of what Leiden art historians have recently coined "living presence response": spectators react to works of art as if they are living beings or even persons that act upon the reviewer, enter into a personal relationship with them, and elicit love, hate, desire or fear. ${ }^{126}$

In short, there and here, in the words of Gordon "the whole inventory is never present" and it is all a matter of "dicing with the impermissible." The concept 'illusion' expresses exactly what I have tried to argue so far: it holds the element of 'playing', of the fictional, and of (self)deception, in our case: the wilful suspension of disbelief, which is nothing else than a (wilful and temporary) shift in definitions or a blurring of classifications or a moving over to a different variant of belief. It also should remind us that the element of theatricality is not restricted to the rituals around a present ruler but also plays a major part in the worship of his 'presence' in a statuesque form.

In order to clarify the concept of henotheism in Chapter III, I quoted Seneca who says: "The God's splendour dazzles them so that they cannot see anything else, and keep their eyes fixed on himself." What I did not mention at that time, in order not to complicate matters, I dare say now: the god mentioned was not a god in the normal sense of that word but the emperor Claudius, who, however, during that 'dazzling'

126 G.L. Hersey, Falling in Love with Statues: Artificial Humans from Pygmalion to the Present (Chicago/London 2009). The new theorists derive their inspiration from anthropologists like A. Gell, Art and Agency (Oxford 1997). 
period was a god. You need only keep your eyes fixed on him and not glance aside. ${ }^{127}$ With a variation on Usener's conception of 'Augenblicksgötter' ${ }^{128}$ I would propose to speak here of 'Augenblicksglauben' ${ }^{129}$ The question that prompts itself next, whether belief can ever be more than 'belief of the moment,' is worth considering but will not be dealt with by the present writer in the present book.

\section{Birds into Gods: Comic Theopoetics}

Men into gods. So far so good. Let us now make a quick excursion to a late 5th-century Greek literary text, which will provide a revealing illumination of my central argument. In the Birds of Aristophanes two elderly Athenians, Peisetairos and his friend Euelpides, set out to find a city where they can henceforth live in peace. When they cannot find such a city they urge the birds to found one. They suggest building a city located between the earthly abode of men and the heavenly abode of the Olympian gods and from that vantage point taking over the sovereign position of the gods. This will turn out to be the opening to another - satirically explicit-construction of new gods displaying precise and revealing - but so far largely unnoticed ${ }^{130}$ - analogies with what we have seen of the construction of deified rulers or doctors (at the expense of the Olympians). ${ }^{131}$

${ }^{127}$ Cf. the remark of Longinus quoted above n. 123.

${ }_{128}$ On the reception of this concept: A. van der Leeuw, Augenblicksgötter, RAC 1 (1950) 969-972.

${ }^{129}$ Note that the complete expression coined by Coleridge quoted above is: "that willing supension of disbelief for the moment." Discussing the divinity of the ruler, Kolde 2003, 369, speaks of his "nature en quelque sorte passagièrement divine."

${ }_{130}$ Following a brief suggestion by O. Weinreich, Antikes Gottmenschentum, Neue Jahrbücher f. Wissenschaft und Jugendbildung 2 (1926) 640 ff., Kleinknecht 1937, $54 \mathrm{n}$. 5 , comments on the final scene of the Birds with the hymn for the new ruler Peisetairos (see below): "Als bis in alle Einzelzüge durchgeführte Parodie der herrscherlichen Epiphanie und Apotheose, die sich ganz in den rituellen Formen und Begriffen vollzieht, die wir aus dem Hellenismus kennen, sei die interessante Schlußszene der Vögel (1706 ff.) hier wenigstens erwähnt." He provides a full treatment of (and restricted to) this 'Parodie einer Herrscherapotheose', in: Zur Parodie des Gottmenschentums bei Aristophanes, ARW 34 (1937) 294-313, espec. 294-306. Horn 1970 only briefly refers to this treatment.

${ }_{131}$ Of course, the highly irreverent scepticism in the Birds, going well beyond that of any other extant comedy, has often been noticed. Its most notorious expression in the threat of starvation of the gods due to human refusal to sacrifice, also figuring in the Homeric Demeter hymn and in the Hesiodic Prometheus myth, has Near Eastern roots: Auffarth 1994a, with a bibliographic survey at p. 66 n.24. The overall 'blasphe- 


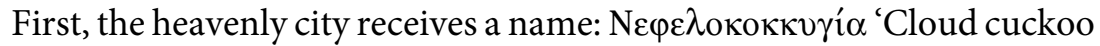
city'. Then there is an interesting development of events. Initially, the birds only take over the power and sovereignty from the gods. This, however, appears to automatically entail their divinisation, which had not been an issue prior to lines $562 \mathrm{f}$., where a herald announces the humans "that, the birds being sovereign, they must henceforth sacrifice to the birds and only afterwards to the gods" ( $\dot{\omega} \varsigma$ opví $\theta \omega v$

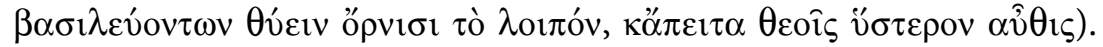
However, the offerings to the birds need only consist of grain, wheat, bread and an occasional roasted gnat. Then the birds, a bit worried, ask (571 f.): "but how are humans supposed to believe us to be gods, ${ }^{132}$

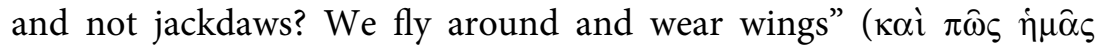

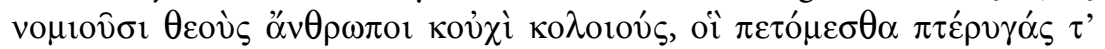
ह' $\chi 0 \mu \varepsilon v ;)$. This is a seminal question, for, indeed, how do you know or

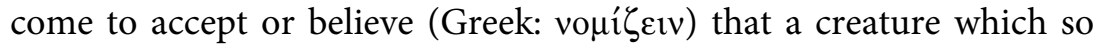
far was not a god is a god? Let us listen to Peisetairos' answer, which I summarize here.

It appears that there are two opposite manners, a negative and a positive one. First, if men in their stupidity think that birds are nothing and that only the Olympians are gods, then let the birds put men and gods to the test by gobbling up the entire harvest on the fields, and by picking out the eyes of all their cattle and next let men see whether the Olympians, more especially Demeter and Apollo, will help them. The phrasing implies that the gods are not really able

mous' atmosphere is sometimes explained as an expression of contemporary sceptical tendencies in Athens, e.g. Nilsson, GGR I 779-782; Greek Piety (Oxford 1948) $77 \mathrm{f}$. Auffarth contests this view, arguing that the utopian promise of the reign of the birds in the end turns into its contrary. In his view, Nephelokokkugia represents the reversed world, and as such evokes the imagery of the Anthesteria, a festival that is not supposed to continue infinitely but must come to an end. Similarly for the Plutus: Bierl 1994. Cf. also: W. Burkert, Götterspiel und Götterburleske in altorientalischen und griechischen Mythen, Eranos Jahrbuch 51 (1982) 335-367. On utopian imagery in comedy see Ch. IV n. 160. On supposed contemporary political influences on the Birds see below n.133. Dunbar 1995, $12 \mathrm{ff}$. has little to contribute to our issue.

${ }_{132}$ This is the translation by J. Henderson, Aristophanes Birds (Loeb Classical Library 2000). Other translators tend to shun the word 'believe' and squirm in their search for an acceptable translation. A.H. Sommerstein, The Comedies of Aristophanes 6, Birds (Warminster 1987): "And how are men going to get the notion that we're gods;" St. Halliwell, Aristophanes Birds (Oxford 1997): "But how will humans ever think we're really gods?;” M.-J. Alfonsi, Théâtre d'Aristophane II (Paris no date): "Mais comment les hommes reconnaîtront-ils que nous sommes des dieux?;" H. Van Daele, Aristophane III (Coll. Budé, Paris 1950): "Et comment les hommes nous tiendront ils pour des dieux?" 
or willing to do so. But if, on the contrary, so Peisetairos continues (586), "men acknowledge that you are gods-that you are Life and you Earth and you Kronos and you Poseidon-all blessings will be at

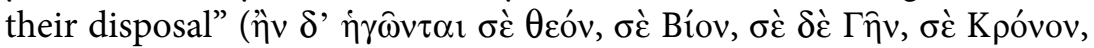

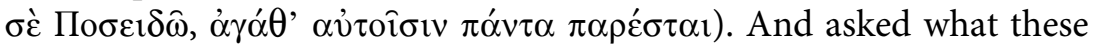
divine blessings should be, Peisetairos mentions a list of things that can be bestowed by birds and which need only a modest redefinition to deserve the label 'divine'.

In a later passage (723 ff.) the new Bird-Gods (кoıvoi $\theta$ coí 848, 862) elaborate on their earlier promise to humankind:

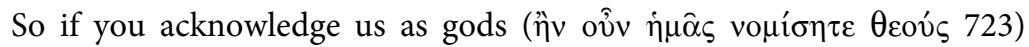
$(\ldots . .$.$) we won't run off and sit with our noses in the air, high in the$

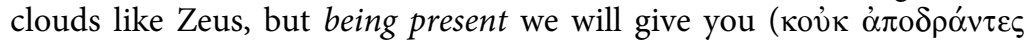

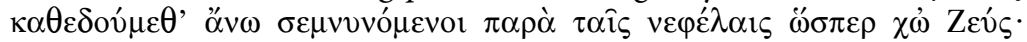
$\dot{\alpha} \lambda \lambda \dot{\alpha} \pi \alpha \rho o ́ v \tau \varepsilon \varsigma \delta \omega ́ \sigma o \mu \varepsilon v \dot{v} \mu i ̂ v . . . .726-9)$ healthy wealth, long life, peace, happiness, youth, laughter and dancing, feasts and birds' milk.

This is Utopian imagery, calling to mind the Golden Age of Kronos, which will return after the rebellion of men against the gods. ${ }^{133}$

Finally, at the end of the play, the great initiator of the new divine city, Peisetairos-who in the course of the play has undergone a gradual metamorphosis into a bird himself (654 f.; 803-806) $)^{134}$ and hence has

133 B. Zimmermann, Utopisches und Utopie in den Komödien des Aristophanes, WJA 9 (1983) 57-77; Dobrov 1997, Chapter 1 "The Theory and Practice of Utopia," 1-134, with a strong focus on Aristophanes' Birds throughout the book; M. Farioli, Mundus alter. Utopie e distopie nella comedia greca antica (Milano 2001). The myth of the struggle for power between the generations of the gods and the Gigantomachy has often been mentioned as the underlying theme of the Birds. See: Dunbar 1995, 7-11. In how far the (Utopian) imagery of the New City is intended as a commentary on contemporary politics and ideas, as has often been suggested, is not of direct relevance to our topic. K. Reinhardt, Aristophanes und Athen, in: idem, Werken und Formen (Bonn 1948) 285 ff. espec. 292 ff., sees Nephelokokkugia basically as an amalgamation of reality, mythical imagination and politics. Bowie 1993, 151-177, espec. 151, argues that the "play is intensely political in its examination of Athenian democracy in general and of the specific political situation at the time of its composition." On the paradoxical interplay of social, political and utopian discourses, see: D. Konstan, A City in the Air: Aristophanes' Birds, Arethusa 23 (1990) 183-207. R. Turasiewicz, The 'Birds' of Aristophanes: A Study of Its Ideas, Eos 84 (1996) 293-298, argues that the comedy stages a parody of contemporary political theories on the ideal state, some more utopian others realistic. Anyway, the play belongs to the most astonishingly candid representatives of satirical freedom of speech among Aristophanes' comedies. See: S. Halliwell, Comic Satire and Freedom of Speech in Classical Athens, JHS 111 (1991) 48-70.

134 Throughout the play there is, for that matter, a persistent pattern of inversion and subversion. Over and over again, men are spoken of as birds, gods as birds or as 
his share in the birds' deification-, with lady Sovereignty (Basileia) ${ }^{135}$ at his side, usurps both the role and the paraphernalia of Zeus. Listen to the hymn announcing his arrival sung by the herald, 1706-1719:

Hail you who enjoy all good fortune, beyond expression, hail you thrice-happy feathered race of the Birds.

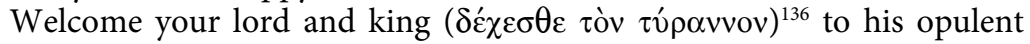
halls.

For he approaches, resplendent more by far than any brilliant star on its path of golden beams or even than the sun's own brilliant splendour.

Such is the radiance flashing out from him. He comes, bringing a lady of beauty surpassing description. He brandishes the thunderbolt, the winged weapon of Zeus. An indescribable fragrance fills the vault of heaven. a fair spectacle, and the wreaths of incense-smoke are wafted apart by the breezes.

men, birds as men or as gods. See: H.-J. Newiger, Metapher und Allegorie. Studien zu Aristophanes (Munich 1957) 86-91; A.H. Sommerstein, The Comedies of Aristophanes 6, Birds (Warminster 1987) 3, who gives the evidence. This sometimes ends up in a confusing amalgamation of roles and characters: in the sacrificial scene the birds are 'upgraded' with divine epithets but one can just as well say that the gods are awarded ornithological epithets. This is a crucial observation for the whole issue of divine epithets.

${ }^{135}$ On the whole ritual of procession and epiphany see: A. Kavoulaki, Processional Performance and the Democratic Polis, in: Goldhill \& Osborne 1999, 293-320, espec. 313-319, who (313) shows the remarkable verbal resemblance with Peisistratos' entry at Athens. On the identity of the "queen" see the fundamental discussion by H.-J. Newiger, o.c. (preceding note) 92-103. Among the many proposed identifications: Athena, Demeter, Queen Sovereignty, Zeus' Sovereignty, in the wake of Kleinknecht and Weinreich, he opts for the latter: "Die Hochzeit des Peithetairos mit der Königin ist ein Bestandteil seiner Epiphanie als neuer Zeus. (.....) In dieser Hochzeit vollzieht sich seine Apotheose und seine Herrschaftsantritt als höchster Gott" (99). See also the full discussion by H. Hofmann, Mythos und Komödie: Untersuchungen zu den Vögeln des Aristophanes (Hildesheim-New York 1976) 147-160. Cf. Dunbar 1995, ad 1537, who in my view rightly refuses to pin down the name on one of the well-known goddesses: "Ar. invented a divine bride for Peis. and named her Basileia." Much to be preferred to the theory of R. Hosek, Zu den thrakischen Gottheiten, Eirene 29 (1993) 31-42, espec. 40, who regards Basileia as a Thracian goddess of the Triballoi. Or also: J. Holzhausen, Pandora und Basileia. Hesiod-rezeption in Aristophanes' "Vögeln", Philologus 146 (2002) 34-45. The only thing of interest to us is that she is a goddess and in her name cannot but symbolize kingship.

136 Turannos is the common term for sovereign in both tragedy and Aristophanean comedy, when referring to mythical rulers. D. Lenfant, Rois et tyrans dans le théâtre d'Aristophane, Ktema 22 (1997) 185-200, demonstrates that turannos and basileus are used indiscriminately in mythical contexts, while for the contemporary historical situation basileus is mainly reserved for barbarian kings (as for instance the Persians) and turannos for the Greek world. 
But here he is in person! Now let the divine Muses open her holy lips in auspicious song.

If I have been rather generous with quotations, this was in order to enable the reader to discover the salient similarities with the various materials of deification that we encountered earlier in this chapter. Aristophanes' Birds presents in a satirical persiflage a near complete picture of the construction of gods as Greeks envisaged it. It corresponds to the detail with the serious play in the deifications of early Hellenistic rulers and other characters: Klearchos, Menekrates, and most of all Demetrios. The analogies include:

- founding a city with a 'heavenly' name;

- cultic forms of worship of mortal creatures (birds and men), including sacrificial meals and the singing of hymns,

- all this as a direct corollary of specific aretai and power. If, in the words of Nock, "miracle (= superhuman feats = $\dot{\alpha} \rho \tau \tau$ ) proves deity," it is no less true that sovereignty attracts the notion of divinity,

- emphasis on the superiority of the new gods over the traditional deities, as exemplified in the antithesis: presence and saving assistance (two semantic aspects of the verb $\left.\pi \alpha \rho_{\rho \varepsilon} \mu \mathrm{l}\right)$ versus distance and inertia, ${ }^{137}$

- in both cases the praise of the new god culminates in a hymn in which the god is welcomed at his advent. He is accompanied by a 'real'though not unequivocally identifiable-goddess and is compared with sun and stars.

The striking similarity between the two hymns might suggest imitation, which, if true, would lend support to an ironic interpretation of the Demetrios hymn. The question remains open; with the exception of Kleinknecht, the resemblance between the two hymns has escaped notice. In my view, we have here an instance of spontaneous analogy as a result of similar motivation in comparable circumstances. No doubt the two hymns were inspired by traditional hymns sung at the

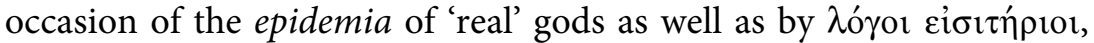
songs sung at the arrival of prominent people, as mentioned earlier in n. 42 .

${ }^{137}$ A good analogon of such a comparison of divine benefactors and the preference of one group due to their superior gifts can be found in Menander fr. 614 (Sandbach) where as against Epicharmos' gods: winds, water, earth, sun, fire, stars, the speaker prefers as useful gods ( $\chi \rho \eta \sigma i ́ \mu o v \varsigma \theta \varepsilon o u ́ \varsigma)$ : silver and gold, since they give everything you wish: a farm, houses, servants, friends, judges, witnesses. 


\section{Making a God: A Multiple Perspective Approach}

Men into gods, birds into gods. The term 'theopoetics' for the processes involved should be taken literally, for men and birds are indeed 'made into' gods. Not only men and birds. In Plato Euthyphro 3,

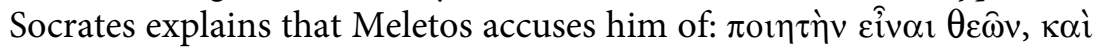

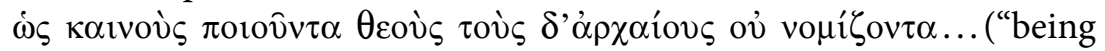
a maker/manufacturer of gods and that while making new gods I do not believe in/acknowledge the old gods"). Most probably the expression 'to make new gods' here refers to the deification of things that were not regarded as divine before: not foreign gods but such things as celestial objects. ${ }^{138}$ Verbs meaning 'to make or create a god' such

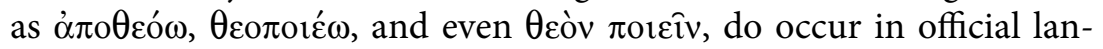
guage, but are not in evidence before the Hellenistic era, most of them not before the imperial period. ${ }^{139}$ One might say that the explicit making (= creating) of new gods in comedy is a deliberately hyperbolic, derisive device as opposed to the implicit making (= recognizing) of gods in 'serious' ruler cult.

In the comedy the birds' pretence is undermined by references to their ornithological menu. ${ }^{140}$ Comedy is a play intended to spoil the rules of the game and in doing so to unmask the sincere pretence as pretence, exposing the emperor's garb as worse than transparent. For this reason it is the most daringly honest type of expression that Athenian culture could boast. Especially so since the whole scene implies

138 P. Ciholas, Socrates. Maker of New Gods, Class. Bull. 57 (1980-81) 17-20; Th.C. Brickhouse \& N.D. Smith, Socrates on Trial (Oxford 1989), 35: "If the charge is to make any sense as a charge of impiety, it must be that Socrates introduces as divinities new entities that are not real divinities at all." Cf. Versnel 1990, 126.

${ }_{139}$ Hiller von Gaertringen, RE s.v. Apotheosis 1896. Full discussion: Habicht 1970, 174-179.

${ }_{140}$ And, of course, through a number of other strategies. One is language. When Peisetairos asks Tereus who will reveal his plan to the birds, Tereus tells him that he can do it himself, since the birds have learned Greek (198-200). Without this little intermezzo Hellenophone birds-being nothing more than an unavoidable narrative device-would not have attracted undue attention. By the mere fact of its mentioning - that is by its being put into focus-, the absurdity of Greek-speaking birds becomes apparent and the effect is laughter. All this just as in the case of Hellenophone Polyphemos (above p. 386). Cf. Bowie 1993, 173: "in this device there is too the tacit admission that even in comedy it is not 'really' possible to create a bird-state without such concessions to dramatic illusion: a chorus saying nothing but 'totinx' and 'kikkabau' would scarcely be tolerable or a credible world force." 
a scathing critique of the gods as well, staging them as the losers in a competition with mortal pretenders.

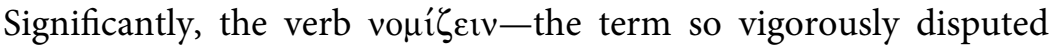
in the discussion on the charge against Socrates $\theta$ coùs oì $\dot{\eta}^{\prime} \pi$ ó $\lambda$ is

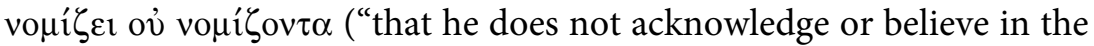
gods whom the polis acknowledges") - appears twice in the passages we discussed. ${ }^{141}$ Once it is the result of a test: if creatures-here the birds-can perform powerful deeds which are normally attributed to the gods, then they are 'acknowledged' as gods. The other time it is in a conditional proposition: only on the condition that they are acknowledged as gods are the divine birds willing to bestow their blessings. Noui ¿ $v$, in religious contexts often-and rightly as I argue in Appendix IV - translated as 'to believe in', appears to be negotiable, a bargaining instrument in a reciprocal relationship, and hence dependent on the qualities offered by the other party.

Exactly the same in ruler cult: the creation of the new god seems to consist first and foremost in his recognition as a god. ${ }^{142}$ There is a variety of expressions: to honour him as a god ( $\dot{\omega} \varsigma \theta \varepsilon o ̀ v \tau \imath \mu \hat{\alpha} \nu \alpha \hat{v} \tau o ́ v$,

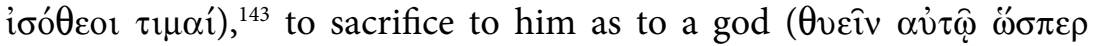

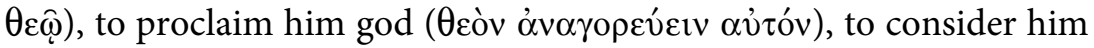

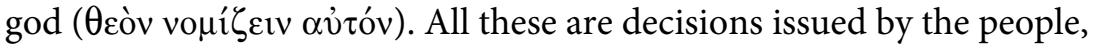
they are acts of recognition in a double sense of that word: acknowledgment of his divine status-inter alia resulting in the predicate theos, very common in inscriptions ${ }^{144}$-and expression of gratituderesulting e.g. in the predicates soter and euergetes. ${ }^{145}$

${ }^{141}$ Once we encounter $\dot{\eta} \gamma \varepsilon \hat{\varepsilon} \sigma \theta \alpha \mathrm{l}$. Fahr 1969, 71-80, discusses the testimonia in the

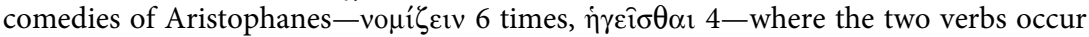
in connection with the god. He demonstrates that, depending on context, the terms occur in different denotations: "take for valid currency," "acknowledge (as)" but also, and undeniably so, "believe in (the divinity or the existence of a god)." See further Appendix IV.

${ }_{142}$ See the fundamental discussion by Habicht 1970, 171-179. At p. 171 he writes: "Der Beschluß der Gemeinde schafft die Göttlichkeit nicht, sondern erkennt sie als bestehend an, er hat somit nicht konstitutiven, sondern deklamatorischen Charakter; mit anderen Wörten: die Stadt kann keine Götter machen."

${ }^{143}$ The evidence for the latter expression: Habicht 1970, 196 n. 23.

${ }^{144}$ Collection of testimonia: Habicht $1970,156 \mathrm{n}$. 75. For a recent survey of the discussion whether theios, generally explained as the translation of Latin divus (hence referring to a deceased emperor) was also applied to living divine rulers like the superlative theiotatos see: J.-Y. Strasser, L'empereur $\mathrm{GEIO \Sigma}$ et une inscription de Laodicée du Lykos, EA 37 (2004) 129-143, espec. 129-136.

${ }_{145}$ Soter and euergetes are royal and divine titles par excellence: P. Wendland, $\Sigma \Omega T H P, ~ Z N T W 5$ (1904) 335-353; W. Schubart, Das hellenistische Königsideal nach 
The evidence presented in this chapter confronts us with interesting, and at first sight astounding paradoxes, if not inconsistencies. Consider, for instance, the culinary allusions that are invoked when it comes to either making a god or unmasking a god as a pretender. When Aristophanes wishes to footnote that the birds are pretenders, he does so by a reference to their bird-food. When king Philippos wishes to expose Menekrates as a pretender he offers him sacrificial food in the form of incense and libations. When, on the contrary, the Athenians wish to proclaim Demetrios a real god, they offer him the very same sacrificial diet of incense and libations. Both presenting and denying mortal food may unmask the pretender, while libations and incense may either construct or deconstruct divinity. Of course, once more this variation is dictated by the differences of occasion, context, target, in sum: focus. What seems to be inconsistent when viewed on one level and from one perspective turns out to represent an enormously productive resource of multiperspective options.

Once more, it is all a matter of focalizing. As we discussed in the fourth chapter, in everyday cult, unlike in myth, the Olympian sacrifice is not-and certainly not consistently, consciously or explicitlyconceived of as a meal for the gods. ${ }^{146}$ During the burning of the meria the focus is not on nourishment, but-if on anything at all (Frits Staal

Inschriften und Papyri, APF 12 (1937) 1-26, espec. 13 ff.; idem, Das Königsbild des Hellenismus, Die Antike 13 (1937) 272-288; A.D. Nock, Soter and Euergetes, in: S.E. Johnson, The Joy of Study. Papers... presented to honor F.C. Grant (1951) 127-48 = idem, 1972, 720-735; Habicht 1970, 156-160. On soter see most recently the abundant literature and discussion in: F. Jung, $\Sigma \Omega T H P:$ Studien zur Rezeption eines hellenistischen Ehrentitels im Neuen Testament (Münster 2002). The predicate euergetes, though, was more frequently applied to human benefactors than to gods. See: F.W. Danker, Benefactor: Epigraphic Study of a Graeco-Roman and New Testament Field (St. Louis 1982); K. Bringmann, The King as Benefactor: Some Remarks on Ideal Kingship in the Age of Hellenism, in: A. Bulloch et alii (edd.), Images and Ideologies. Self-definition in the Hellenistic World (Berkeley 1993) 7-24. In the same period euergetism developed as a social phenomen: P. Veyne, Le pain et le cirque. Sociologie historique d'un pluralisme politique (Paris 1976) 185-374; Gauthier 1985. Concrete expressions of this euergetism are documented in the donations of Hellenistic rulers to cities in: W. Ameling et alii, Schenkungen hellenistischer Herrscher an griechische Städte und Heiligtümer I, Zeugnisse und Kommentar (Berlin 1995). This royal quality as incentive to ruler cult is specifically emphasized by Habicht 1970, espec. 222-229. Cf. above n. 51. Demetrios Poliorketes himself in his attempt to persuade the Athenians to let him go through all three stages of the Eleusinian initiation at once (and in the wrong

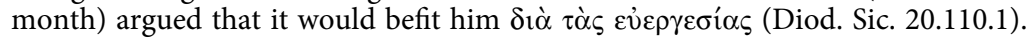

${ }^{146}$ On the polysemantics of sacrifice see recently: Van Straten 2006. 
is not entirely wrong $)^{147}$-on communication. As soon, however, as the focus shifts towards alimentary notions, funny things happen. Suddenly one may become aware that knise does not represent the height of nutrition. Consequently, a wealth of puns and practical jokes becomes available as daggers to the hands of comic authors, philosophers, detractors of popular belief, and of the royal joker Philippos. So-as so often before-one should beware of mixing up registers. ${ }^{148}$ That is what king Demetrios and his spectators kept in mind, thusfor the moment-successfully escaping mocking reactions.

The essential observation, however, is that it is all in the hands of man, who is, to quote Socrates, $\pi$ oin of gods) and has the power to decide whether or not to acknowledge

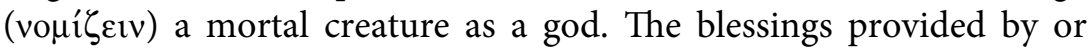
expected from the new god may differ in their nature. As we remarked earlier rulers were not the only and not the earliest mortals of whom we hear that they received divine cultic honours in Greece. Especially in the classical and early Hellenistic periods, which are our present concern, we have evidence for cultic honours for philosophers, athletes, and doctors. But what then is the final decisive factor in the dilemma of acknowledging or denying divinity? In order to find an answer we need one last little, but revealing, piece of information.

The same king Philippos who played his unholy little game with doctor Menekrates Zeus had himself been enjoying divine honours already since $357 \mathrm{BC}$. The inhabitants of Amphipolis brought sacrifices to him as to a god (Ael. Arist. Or. 38.715D: है $\theta$ vov $\dot{\omega} \varsigma \theta \varepsilon \hat{\omega}) .{ }^{149}$ And at

147 There is perhaps some truth in the idea that "learning a practical or social skill means removing the procedures from consciousness," as argued by P.B. Medawar, Does Ethology Throw any Light on Human's Behaviour?, in: P.P.G. Bateson \& R.A. Hinde (edd.), Growing Points in Ethology (Cambridge 1976). In other words, if many skills acquired by cultural learning are applied-and can be only consistently applied-by switching off conscious consideration, this does not do much to support the idea that expression or meaning are dominant elements in communicative skills and techniques such as sacrifice.

${ }_{148}$ Or in the words of J.Z. Smith 1982, 55, particularly fitting the present issue: "The dilemma for the ritualist is that if everything signifies, the result will be either insanity or banality. Understood from such a perspective, ritual is an exercise in the strategy of choice. What to include? What to hear as a message? What to see as a sign? What to perceive as having double meaning? What to exclude? What to allow to remain as background noise? What to understand as simply 'happening'? It is all about the economy of signification."

149 See: Habicht 1970, $11 \mathrm{ff}$. On sacrificing 'as if to a god or a heros in Pausanias, see recently: Pirenne-Delforge 2008, 187-207: Sacrificier "comme à un dieu" ou "comme à un heros." 
the occasion of a theatrical festival he had his own statue carried along in the procession of the twelve gods, thus becoming the triskaidekatos theos, the thirteenth Olympian, as Weinreich has argued. ${ }^{150}$ The ambiguity that is the central issue of this chapter manifests itself in an exemplary way if we also know that the same king had himself daily reminded by a slave that he was a mortal being: ö $\tau$ ö $v \theta \rho \omega \pi \circ \varsigma \dot{\varepsilon} \sigma \tau \imath$. Receiving sacrifices as a god, playing the thirteenth god, yet realizing that you are a mortal being: that is what I would call double awareness, what the Greeks called $\dot{\pi} \alpha \mu \varphi \circ \tau \varepsilon \rho i \zeta \varepsilon ı v$, and what in Victor Turner's terms is the simultaneity of 'as if and 'as is'. ${ }^{151}$

So what then is the decisive reason for acknowledging Philippos' and denying Menekrates' divinity? In other words: what is the difference between Menekrates and Philippos? The once popular answer,

150 Diod. 16.92.6 and 95.1. Even the sceptic Hammond 1999, 107 and n.14, admits that here the king was indeed "equalling himself with the gods," and at p. 13 draws further conclusions for other events. Divine cult during his lifetime for Philippos is now solidly attested for the city of Philippi (SEG 38.658), where an epigraphical list of possessors of sacred land mention Philippos among gods (Ares and Poseidon) and heroes.

${ }_{151}$ That such ambiguous behaviour was in complete concordance with the king's nature-and indeed with the program of the beginning ruler cult-is splendidly illustrated by the round Philippeion at Olympia, which initially contained the chryselephantine statues of Philippos II, Alexander, Philippos' father, Amyntas, Olympias, and Philippos' mother Eurydice. Concerning the function and nature of this building there has been much discussion, although most scholars agree that it was an explicitly dynastic monument. Recent scholarship, however, seems to agree on its basic-and intentional-ambiguity. See: E.N. Borza, In the Shadow of Olympus: The Emergence of Macedon [Princeton 1990] 250; C. Wikander, Religion, Political Power, and Gender. The Building of a Cult Image, in: P. Hellström \& B. Alroth (edd.), Religion and Power in the Ancient Greek World, Proceedings of the Uppsala Symposium 1993 (Uppsala 1996) 183-188; E.D. Carney, The Initiation of Cult for Royal Macedonian Women, CPh 95 (2000) 21-43, espec. 24 ff.; O. Palagia, Philip's Eurydice in the Philippeum at Olympia, in: Carney \& Ogden 2010, 33-41. I quote here the apt formulations of Carney 2000, 212 f.: "The Philippeum looked like a temple (...). It contained statues that looked like cult statues, yet there is no evidence for divine cult. It was not a temple. (...) Its shape resembled that of heroa but there is no evidence for heroic honors. It was not a heroon. We know what it was not but cannot be sure what it was, and that is the point. What was it then? Philip offered those who visited the Panhellenic shrine a way to think about the power he had come to exercise. The Philippeum did not assert that this power was divine, but it implied that it might be and suggested that this power was like the power of the gods. It parallels his decision to have his own statue appear with that of the twelve Olympians." Cf. also eadem, Olympias: Mother of Alexander the Great (New York - London 2006) 88-103, on the queen's attitude vis-à-vis the question of deification. This is a perfect-but not unique-plastic transformation of the ambiguity that we detected earlier in the verbal rhetoric of ruler adulation. There and here the art was to leave options open and available for momentary shifts in interpretation: 'Augenblicksglauben'. The world of 'as if makes an invasion into the world of 'as is.' 
now long antiquated, that the first was a lunatic and the latter a clever politician - thus by implication on the one hand marginalizing and on the other politicizing the cult of (Greek) mortals and keeping the two nicely apart-simply does not work. Of course the first thing that comes to mind is the difference in social and political status, the difference between the sphere of the private person and that of public royal authority, including their respective social and cultural platforms. Yet Klearchos, closer to Menekrates than to Philippos in terms of his theatrical behaviour, was the learned brother of a king and ruled over a kingdom himself.

Another factor may have been that Menekrates impersonated a specific individual god, even the supreme god, while rulers generally were honoured as $a$ god, but not as a specific individual god. However, as we have seen, here, too, there are exceptions and the boundaries between the two representations are far from neat. For one thing, the distinction between a mortal elevated to divinity and a god descending and appearing on earth in the shape of a mortal is difficult to make, as Antiochos IV, who identified himself with Zeus Kataibates, demonstrated, and as Paul and Barnabas experienced in a different manner.

In my view the essential difference is spelled out in the sources we have read. Philippos honestly played the god and was man. Vere deus vere homo. He reserved the 'as if' simultaneity for ritual occasions, where it belongs and which it helps to define. Menekrates, on the other hand, never stopped 'playing the god', thus never leaving his subjunc-

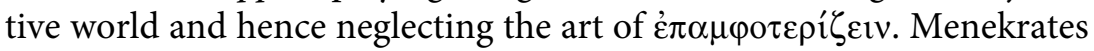
(like Alexarchos and similar later ones) did not keep to the rules of the game. ${ }^{152}$ The result is that Menekrates fatally reduced the necessary range of different discourses to a single-the ludic-one, thus cancelling normal communication.

The anthropologist Maurice Bloch ${ }^{153}$ suggests that ritual makes its statements appear powerful or holy by reducing the creativity of

${ }^{152}$ Cf. Pruyser 1968, 190: "Playing requires a circumscribed play space [and as I already suggested in connection with J.Z. Smith's 'taking place'-and as Pruyser himself stresses elsewhere in the same context-, we should add "and a circumscribed play time"]. Within that play space (and time) there are definite rules: the rules of the game. They are invalid outside that space (and time), and they hold only as long as the play or game lasts."

${ }^{153}$ M. Bloch, Symbols, Song, Dance and Features of Articulation: Is religion an extreme form of traditional authority?, Archives Européennes de Sociologie 15 (1974) $55-81=$ Bloch 1989, 19-45. I owe the reference to this very important paper to 
syntax (as for instance in stylized speech or singing). This leads to semantic processes different from more ordinary forms of communication. The latter deal with reality, with the interplay of perception and communication. They can be used to report facts, and, characterized by 'propositional force,' they have meaning potential (comparable to Turner's 'as is'); the first do not relate in any immediate way to reality, indeed are often used to hide reality and are by Bloch characterized as having 'illocutionary force' or 'performative force' (comparable to Turner's 'as if'). According to Bloch this means that ritual implies the loss of the "very potential for communication" (that is that type of communication that we know from daily life). ${ }^{154}$ Adopting Bernstein's concept of 'restricted code', ${ }^{155}$ Bloch argues that the formalization of ritual speech therefore dramatically restricts what can be said, so the speech acts are either all alike or all of a kind and thus there is hardly any choice of what can be said: "You cannot argue with a song." At p. 42 he gives a perfect summary of what I have tried to argue in the present chapter:

The study of ritual should avoid two things: 1) jumping from the inside of religious discourse to everyday speech when producing an explanation, and 2) either directly or indirectly using logical forms.

Bloch's observations may serve as a critical warning to those who would stretch the principle of subjunctive simultaneity in premodern societies as encompassing the total reality of social and cultural life. Rather, in these societies, too, it is restricted to situations that require a 'make believe', situations that, however, are more universal and pervasive in that pre-modern world. By monopolizing the 'as if' Menekrates transgressed the boundaries of the ludic, hence made himself unavailable

Naerebout 1997, 333 ff., who provides an interesting critical discussion. See now: Kowalzig 2007, 49-53, for praise and creative use of Bloch's ritual theory.

154 At p. 33 he calls this "communication which excludes explanation." Hence, in the ritual language there are no alternatives, and no contradictions, and thus no logic.

155 B.A. Bernstein, Class, Codes and Control 1: Theoretical Studies towards a Sociology of Language (London 1974) $76 \mathrm{ff}$. Transposed to visual art this is in the words of E. Gombrich, 'L'image visuelle' in: L'écologie des images (Paris 1983) 323-349, 'exprimer' rather than 'communiquer' (communication, which like Bloch he here understands as sharing explicit and expressible notions). Hence the reception of an image is at most a 'communication faible' or 'communication problématique' in the words of J.-Cl. Passeron, 'L'usage faible des images', in: Le raisonnement sociologique: l'espace non-poppérien du raisonnement natural (Paris 1991) 281-288, who also coins the terms 'non assertorique' or 'quasi assertorique'. 
for normal 'as is' communication. Contrarily, Philippos knew the art of $\dot{\pi} \alpha \mu \varphi о \tau \varepsilon \rho i \zeta \varepsilon ı v$. So did other Hellenistic kings and Roman emperors after him, with those exceptions that exactly illustrate my point: Antiochos Epiphanes, Caligula, Nero, Domitian, the latter two more or less. Now, if I am reminded that this distinction largely concurs with the accepted modern definition of mental disturbance as opposed to mental health, I have nothing to object. It still leaves us, though, with Philippos and a host of epigones on the 'good' side of the boundary line between normal and abnormal, yet performing very funny ritual acts, which a former generation of scholars contended (the) Greeks

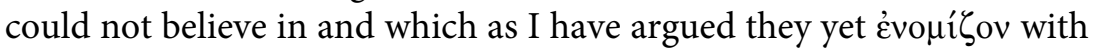
the honest hypocrisy of a ritual 'Augenblicksglauben'. And that is what all this was about. 